\title{
Electrical energy storage with engineered biological systems
}

\author{
Farshid Salimijazi ${ }^{1}$ Erika Parra ${ }^{2}$ and Buz Barstow ${ }^{1 *}$
}

\begin{abstract}
The availability of renewable energy technologies is increasing dramatically across the globe thanks to their growing maturity. However, large scale electrical energy storage and retrieval will almost certainly be a required in order to raise the penetration of renewable sources into the grid. No present energy storage technology has the perfect combination of high power and energy density, low financial and environmental cost, lack of site restrictions, long cycle and calendar lifespan, easy materials availability, and fast response time. Engineered electroactive microbes could address many of the limitations of current energy storage technologies by enabling rewired carbon fixation, a process that spatially separates reactions that are normally carried out together in a photosynthetic cell and replaces the least efficient with non-biological equivalents. If successful, this could allow storage of renewable electricity through electrochemical or enzymatic fixation of carbon dioxide and subsequent storage as carbon-based energy storage molecules including hydrocarbons and non-volatile polymers at high efficiency. In this article we compile performance data on biological and non-biological component choices for rewired carbon fixation systems and identify pressing research and engineering challenges.
\end{abstract}

Keywords: Synthetic biology, Energy storage, Electrosynthesis, Rewired carbon fixation, Sustainable energy, Autotrophic metabolism, Sulfur oxidation, Hydrogen oxidation, Extracellular electron transfer

\section{Background}

The penetration of renewable electricity sources like wind, solar, and wave is significantly increasing across the world thanks to their growing maturity and an increasing pressure to control climate change. These same forces are also driving the electrification of transportation, considerably increasing demands on the electrical grid. However, it's well known that unlike traditional electricity sources, the power output of most renewables is variable at best, and completely unreliable at worst [1]. In order to replace a large fraction of the current electricity supply with renewable sources and enable electrified transportation, electrical energy storage at low-cost and large scale will be essential.

How much electricity storage will be needed? Systematic modeling studies indicate that as the percentage of renewables on the grid increases, the amount of electricity storage needed to support them grows exponentially

\footnotetext{
*Correspondence: bmb35@cornell.edu

${ }^{1}$ Department of Biological and Environmental Engineering, Cornell University, Ithaca, NY 14853, USA

Full list of author information is available at the end of the article
}

[2], but considerable disagreement remains on just how much storage is needed [2]. At the time of writing, the US consumes electricity at a rate of $\approx 500$ gigawatts (GW) [3] (total US energy consumption is $\approx 3$ terawatts (TW) [4]). Frew et al. predict that to support an $80 \%$ renewable electricity portfolio in the US, between 0.72 and 11.2 petajoules (PJ; 1 PJ $=1 \times 10^{15} \mathrm{~J}$ or 277.8 gigawatt-hours $(\mathrm{GWh}))$ of storage are needed $[2,5]$. By contrast, Shaner et al. predict that 20 PJ of storage, about 12 hours of supply, will be needed to support $80 \%$ renewables [6]. To implement a 100\% renewable electricity portfolio in the US, Frew et al. estimate that between 6 (without electric vehicles) and 21 (with electric vehicles) PJ of storage would be needed [2, 5, 7]. Shaner et al. make an even bigger prediction, that several weeks of stored supply will be needed to support $100 \%$ renewables [6]. A three-week supply of $500 \mathrm{GW}$ of power amounts to 900 PJ. Projections for Europe are similar: $80 \%$ renewables need between 0.65 to 9 PJ of storage [2], while $100 \%$ requires 0.95 to 35 PJ. As economic development spreads around the world, and more and more of the global energy infrastructure is electrified (think 
electric vehicles) global electricity consumption will rise. Assuming that all of the 11 billion people who are projected to be alive in 2100 [8] use electricity at the rate that the average American does today $(\approx 1.4$ kilowatts) [9], this would correspond to a global electricity demand of $\approx 15$ terawatts (TW). This may even be an underestimate, as electricity corresponds to less than $20 \%$ of US energy use per capita today [3]. Adding electrified transport into this picture could considerably increase global electricity use above $15 \mathrm{TW}$. A one-hour buffer for 15 TW would require $51 \mathrm{PJ}(14,000 \mathrm{GWh})$ of storage, 12 hours would require 618 PJ, and three weeks would require 26 exajoules $\left(E J ; 1 \times 10^{18} \mathrm{~J}\right)$. These projected storage capacities are summarized in Table 1. Currently, the installed energy storage capacity in the US amounts to only $\approx 1$ GWh (0.0036 PJ) [10]), while worldwide it stands at $\approx 20 \mathrm{GWh}(0.072 \mathrm{PJ})$ [11]. How could an increase in electrical energy storage of this size be achieved?

No modern energy storage technology is perfect. Compressed air and pumped-hydro storage both have high durability $[12,13]$. However, there are relatively few suitable sites for installation of either of these technologies. In addition, compressed air storage has low round trip energy storage and retrieval efficiency while the installation of pumped hydro requires a high capital investment [14]. Flow batteries scale up extremely well: their capacity is only determined by the concentration and volume of their electrolyte [14, 15]. However, current flow batteries suffer from low performance due to non-uniform pressure drops [16]. Furthermore, disposal of flow battery electrolytes poses significant environmental concerns [14]. Conventional batteries have fast response times as short as a few milliseconds [14, 17], offer an excellent combination of energy and power density for on-grid applications, and can be situated almost anywhere, making them highly scalable [18]. However, further improvements in power density in Li-batteries by decreasing the cathode thickness are limited by dendrite formation $[19,20]$. The most pressing concern with all battery technologies are limited cycle and calendar lifespans. For example Li-ion batteries typically have lifespans of only 5 to 15 years or 1,000 deep charge-discharge cycles [21].

In the absence of effective recycling technologies for battery materials, the short lifespans of batteries will be significantly exacerbated by the challenges of materials availability. The total mass of electrode material, $M_{\text {elec- }}$ trode (in grams), needed to build a battery with a capacity $E_{\text {battery }}$ (in joules), depends on the mass of metal needed to store a unit of energy $\mu_{\text {metal }}$ (in grams per joule),

$$
M_{\text {electrode }}=E_{\text {battery }} \times \mu_{\text {metal }}
$$

The minimum value of of $\mu_{\text {metal }}$ can be estimated from the molecular weight of the electrolyte material

Table 1 Estimated $\mathrm{Li}$ and $\mathrm{Zn}$ requirements for a representative set of energy storage scenarios

\begin{tabular}{|c|c|c|c|c|c|c|}
\hline Scenario & $\begin{array}{l}\text { Storage } \\
\text { Requirement } \\
\text { (Petajoules) }\end{array}$ & $\begin{array}{l}\text { Amount of } \mathrm{Li} \\
\text { (theoretical } \\
\text { minimum) (kilotonnes) }\end{array}$ & $\begin{array}{l}\text { Amount of Li } \\
\text { (practical) } \\
\text { (kilotonnes) }\end{array}$ & $\begin{array}{l}\text { Fraction of } \\
\text { World Reserve }\end{array}$ & $\begin{array}{l}\text { Amount of } \mathrm{Zn} \\
\left(e^{-}\right) \text {(kilotonnes) }\end{array}$ & $\begin{array}{l}\text { Fraction of } \\
\text { World Reserve }\end{array}$ \\
\hline $\begin{array}{l}\text { Ballpark low estimate for US or EU energy } \\
\text { storage requirements, } 80 \% \text { renewables. }\end{array}$ & 1 & 19 & 47 & 0.003 & 565 & 0.002 \\
\hline $\begin{array}{l}\text { Low end estimate for } 100 \% \text { renewables } \\
\text { in US, no EVs (Frew et al.) }\end{array}$ & 6 & 117 & 283 & 0.018 & 3,390 & 0.015 \\
\hline $\begin{array}{l}\text { Ballpark estimate for US or EU energy } \\
\text { storage requirements, } 100 \% \text { renewables. }\end{array}$ & 10 & 195 & 472 & 0.030 & 5,650 & 0.025 \\
\hline $\begin{array}{l}\text { Upper end estimate for } 80 \% \text { renewables } \\
\text { in US ( } 12 \text { hours of power) (Shaner et al.) }\end{array}$ & 21 & 409 & 992 & 0.064 & 11,900 & 0.052 \\
\hline $\begin{array}{l}\text { Upper end estimate for } 100 \% \text { renewables } \\
\text { in US ( } 3 \text { weeks of power) (Shaner et al.) }\end{array}$ & 900 & 17,500 & 42,500 & 2.72 & 509,000 & 2.21 \\
\hline $\begin{array}{l}\text { Current world ( } 2.5 \text { TW), } 12 \text { hours of } \\
\text { current supply }\end{array}$ & 108 & 2,100 & 5,100 & 0.323 & 61,000 & 0.266 \\
\hline $\begin{array}{l}\text { Current world ( } 2.5 \mathrm{TW}), 3 \text { weeks of } \\
\text { current supply }\end{array}$ & 4,540 & 88,300 & 214,200 & 13.7 & $2,560,000$ & 11.2 \\
\hline $\begin{array}{l}\text { Future World, US energy consumption } \\
\text { is standard, } 11 \text { billion people, } 1 \text { hour } \\
\text { supply (14.3 TW) }\end{array}$ & 51 & 1,000 & 2,430 & 0.156 & 29,100 & 0.127 \\
\hline $\begin{array}{l}\text { Future World, US energy consumption } \\
\text { is standard, } 11 \text { billion people, } 12 \text { hours } \\
\text { supply (14.3 TW) }\end{array}$ & 618 & 12,000 & 29,200 & 1.87 & 349,000 & 1.52 \\
\hline $\begin{array}{l}\text { Future World, US energy consumption is } \\
\text { standard, } 11 \text { billion people, } 3 \text { weeks } \\
\text { supply }\end{array}$ & 25,900 & 505,000 & $1,230,000$ & 78.5 & $14,670,000$ & 63.8 \\
\hline
\end{tabular}


( $\mathrm{MW}_{\text {metal, }}$ in the case of $\mathrm{Li}$ this is 6.941), the valence state of the electrolyte $\left(n_{e}\right.$, in the case of $\mathrm{Li}$ this is 1$)$, and the cell voltage $\left(V_{\text {cell }}\right)$,

$$
\mu_{\text {metal }}=\frac{\mathrm{MW}_{\text {metal }}}{V_{\text {cell }} \times e \times N_{\mathrm{A}} \times n_{e}} .
$$

For lithium nickel manganese cobalt oxide (LiNMC; LiNiMnCoO ${ }_{2}$ ) and lithium nickel cobalt aluminum oxide $\left(\mathrm{LiNCA}\right.$; $\left.\mathrm{LiNiCoAlO}_{2}\right)$ cells, where $V_{\text {cell }}$ is $3.7 \mathrm{~V}, \mu_{\text {metal }}=$ $1.95 \times 10^{-5} \mathrm{~g} \mathrm{~J}^{-1}\left(70 \mathrm{~g} \mathrm{kWh}^{-1}\right)$. In practice more than double this amount of $\mathrm{Li}$ is needed $\left(\approx 170 \mathrm{~g} \mathrm{kWh}^{-1}\right.$ or $4.72 \times 10^{-5} \mathrm{~g} \mathrm{~J}^{-1}$ ) [22]. Thus, in order to store $1 \mathrm{PJ}$ of energy, between 19.5 and 47.2 kilotonnes of $\mathrm{Li}$ is required.

The total estimated masses of $\mathrm{Li}$ and $\mathrm{Zn}$, along with the fractions of world proven reserves, needed to build the Li-ion or alkaline batteries for a wide range of projected energy storage scenarios are shown in Table 1. While current proven global $\mathrm{Li}$ and $\mathrm{Zn}$ reserves can easily supply the energy storage needs of Europe and the US for decades to come, should global renewable energy demand continue to rise, then global supplies of these important metals could be rapidly overwhelmed.

Many innovations will be required to allow high penetration of renewables into the global electricity supply without building a large excess of renewable capacity. New environmentally-friendly, low-cost recycling technologies for battery materials will be essential, some of which may be biological [23]. Likewise, new technologies for the synthesis of batteries at room temperature and pressure will be needed to reduce the embedded energy and carbon footprint of energy storage [24-26]. Finally, as we discuss in this article, a crucial innovation will be the development of biologically based storage technologies that use Earth-abundant elements and atmospheric $\mathrm{CO}_{2}$ to store renewable electricity at high efficiency, dispatchability and scalability.

\section{Biology Gives a First Draft Template for Storing Renewable Energy}

Biology, through photosynthesis, gives a first draft template for storing solar energy at an enormous scale. Across the globe, it's estimated that photosynthetic organisms capture solar power at an average rate of $\approx$ 4,000 $\mathrm{EJ} \mathrm{yr}^{-1}$ (corresponding to an annually averaged rate of $\approx 130$ terawatts $(\mathrm{TW})$ ) [27]. This energy capture rate is approximately 6.5 times greater than current world primary energy consumption of $20 \mathrm{TW}$ [28]. Terrestrial photosynthetic organisms store this energy, after losses of carbon due to respiration, at a net rate of $\approx 1,200 \mathrm{EJ}$ $\mathrm{yr}^{-1}$ (or $\approx 38 \mathrm{TW}$ ) largely as lignocellulosic biomass [29]. Capturing this energy requires $\approx 120$ gigatonnes of carbon per year $\left(\mathrm{GtC} \mathrm{yr}^{-1}\right)$ (counting just the carbon atoms in fixed $\mathrm{CO}_{2}$ ) [30], while storing it requires $\approx 60 \mathrm{GtC}$ $\mathrm{yr}^{-1}$ [31], accounting for between only 7 and $14 \%$ of the global atmospheric pool of carbon [32, 33].

However, photosynthesis is far from perfect. Photosynthesis draws carbon from the atmosphere at an annually averaged rate of only 1 to $2 \times 10^{18}$ molecules of $\mathrm{CO}_{2} \mathrm{~m}^{-2}$ $\mathrm{s}^{-1}$ [34], between 25 and 70 times less than the maximum possible uptake rate of carbon from the atmosphere of 5 to $7 \times 10^{19}$ molecules of $\mathrm{CO}_{2} \mathrm{~m}^{-2} \mathrm{~s}^{-1}[34,35]$. As a result, the globally and annually averaged efficiency of photosynthesis ranges from between $0.25 \%$ [35] to $1 \%$ [36], with the best overall efficiencies seen in the field of between $2.4 \%$ for $C_{3}$ plants [37], $3.4 \%$ for $C_{4}$ plants [38] and $3 \%$ for algae grown in bubbled photobioreactors [39]. These observed efficiencies fall well below the theoretical maximum efficiencies of $\mathrm{C}_{3}, \mathrm{C}_{4}$, and algal photosynthesis of $4.6 \%, 6 \%$ [40], and 9\% [39] respectively. Additionally, photosynthesis is not immediately dispatchable: it takes an entire growing season to store solar energy as plant biomass, followed by harvesting and a long series of thermochemical steps to extract energy from it.

\section{Components of Re-wired Carbon Fixation Overview}

Previous analysis by us suggests that much of the inefficiency of photosynthesis arises because all of the steps of natural photosynthesis happen inside a single cell [41, 42]. Simply put, a single cell is much better at absorbing light than it is at fixing $\mathrm{CO}_{2}$, even when packed with the $\mathrm{CO}_{2}$-fixing enzyme RuBisCO. The cell absorbs far more light than it can possibly use to fix $\mathrm{CO}_{2}$, and dissipates the excess as heat. This leads to inefficient parallelization of the $\mathrm{CO}_{2}$-fixation process, and causes the efficiency of photosynthesis to drop well below its theoretical maximum [41, 42].

The rate mismatch between the light absorption and $\mathrm{CO}_{2}$-fixation capability in a single cell have led to attempts to rewire photosynthesis by spatially separating each of the tasks usually performed together inside a photosynthetic organism and replacing some of them with non-biological equivalents. These schemes are often called microbial electrosynthesis, or more recently rewired carbon fixation. Although originally meant to enable capture and storage of solar energy as biofuels with much higher efficiencies than photosynthesis, this separation enables the use of biology to store energy from any electrical source. A schematic of the key components of a rewired carbon fixation system is shown in Fig. 1: sustainable energy capture (Fig. 1a); water splitting (Fig. 1b); electrochemical $\mathrm{CO}_{2}$-fixation (Fig. 1c) and further biological reduction (Fig. 1d) or biological $\mathrm{CO}_{2}$-fixation (Fig. 1e); long-range electron transport to biological metabolism (Fig. 1f); and energy storage molecule synthesis (Fig. 1g). Capture of energy from sustainable energy sources (including light) (Fig. 1a), water splitting (Fig. 1b), and even the initial steps of 


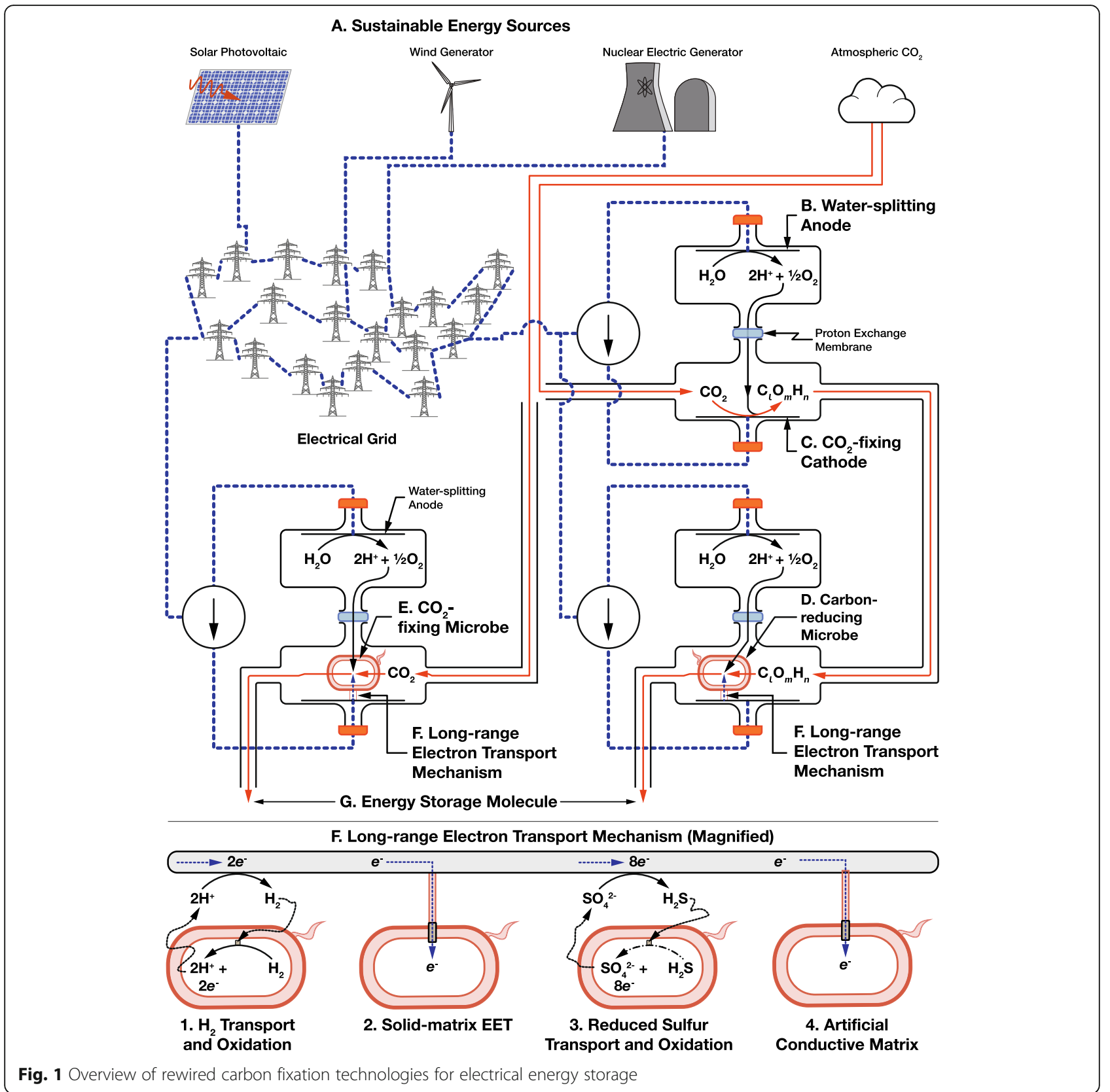

$\mathrm{CO}_{2}$-fixation (Fig. 1c) can now be replaced by non-biological processes, but full reduction of carbon (Figs. 1d and e) and the synthesis of complex molecules (Fig. 1g) remains exclusively the job of biology.

Several demonstrations of rewired carbon fixation have already been made, some with efficiencies exceeding that of natural photosynthesis [43-45]. However, to date, while we have previously reviewed some of constraints faced by these systems [41], no one has made a systematic review of the potential energy losses in these systems, made an upper estimate of the potential energy storage efficiency of these systems, or identified the trade-offs that the components of these systems must make. In this article, we seek to identify and catalog the parameters necessary to make this estimate, and we further identify components of the system that could be optimized by biological engineering.

\section{Long-range Electron Transport and Uptake}

Because rewired carbon fixation separates processes that were once performed inside a single cell, it needs mechanisms to move electrons and partially reduced carbon between components of the system that are separated by distances much longer than a single cell. Long-range electron transport and electron uptake mechanisms from non-light driven autotrophic metabolisms to move 
electrons from a cathode to intracellular reductants where they can be used to reduce carbon is the defining feature, and key challenge, of rewired carbon fixation. The choice of electron transfer mechanism could open up unique opportunities for the design of the system, but also set unique constraints.

The two most prominent mechanisms for long-range electron transport used in rewired carbon fixation to date are the transport of hydrogen to $\mathrm{H}_{2}$-oxidizing microbes $[45,46]$ and solid-matrix extracellular electron transfer (SmEET) enabled by conductive pili secreted by electroactive microbes [41, 47]. However, these well-known mechanisms come with a number of drawbacks including rate, safety, and poor genetic tractability. Alternative electron transport mechanisms that rely upon transport and oxidation of reduced sulfur compounds, and artificial conductive matrices could solve many of these limitations.

\section{Hydrogen Transport and Oxidation}

On the face of it, hydrogen has many attractive features as an electron transport mechanism for rewired carbon fixation. Its redox potential is well matched to that of $\mathrm{NAD}(\mathrm{P}) \mathrm{H}$, the intracellular reductant used in $\mathrm{CO}_{2}$-fixation and many biosynthetic reactions $(-0.42 \mathrm{~V}$ vs. the Standard Hydrogen Electrode (SHE) for $2 \mathrm{H}^{+}+2 \mathrm{e}^{-} / \mathrm{H}_{2}$; and $-0.32 \mathrm{~V}$ vs. SHE for $\left.\mathrm{NAD}(\mathrm{P})^{+}+2 \mathrm{e}^{-} / \mathrm{NAD}(\mathrm{P}) \mathrm{H}\right)$. It can be readily produced electrochemically with high Faradaic efficiency (> $90 \%$ [48]) under optimized conditions, and then easily transported to a microbial culture in the gas phase; and unlike other low redox potential redox mediators like methyl viologen $[49,50]$ has no negative effect on microbial integrity [51].

In addition to these physicochemical advantages, $\mathrm{H}_{2}$ is oxidized at the cell by highly active hydrogenase enzymes that impose a very low protein load on the host cell [41]. In the $\mathrm{H}_{2}$-oxidizing, $\mathrm{CO}_{2}$-fixing microbe Ralstonia eutropha, $\mathrm{H}_{2}$ is oxidized by an inner membrane-bound hydrogenase $(\mathrm{MBH})$ and a cytoplasmic soluble hydrogenase (SH). The membrane-bound hydrogenase injects electrons from $\mathrm{H}_{2}$-oxidation into the electron transport chain on the inner membrane, eventually reducing $\mathrm{O}_{2}$ and creating a proton gradient, which is used to generate ATP [52]. The soluble hydrogenase directly reduces $\mathrm{NAD}^{+}$to NADH [53]. R. eutropha uses the ATP and NADH to fix $\mathrm{CO}_{2}$ through the Calvin cycle and further concatenate and reduce it to the energy storage polymer polyhydroxybutyrate (PHB) [54]. This pathway can be repurposed to produce fuels like isobutanol [43], or isopropanol [45] from electrochemically reduced $\mathrm{H}_{2}$.

A rewired carbon fixation system using $\mathrm{H}_{2}$ produced by a Co-P alloy electrode with low overpotential coupled with $\mathrm{CO}_{2}$-fixation and biofuel synthesis by $R$. eutropha has already achieved maximum electrical to fuel conversion efficiencies of 39\%. Assuming an 18\% efficient solar photovoltaic, this corresponds to a solar to fusel alcohol efficiency of 7.1\% [45]. This significantly exceeds the efficiency of photosynthesis in many practical situations and almost matches the maximum theoretical efficiency of algal photosynthesis (the most efficient form of photosynthesis). However, it remains unclear how far the efficiency of this system is from its theoretical maximum, nor does a roadmap exist for achieving this efficiency, particularly through biological engineering.

The scale-up of $\mathrm{H}_{2}$-mediated rewired carbon fixation poses several challenges. First, in order to extract maximum energy from $\mathrm{H}_{2}, \mathrm{O}_{2}$ is needed as a terminal electron acceptor. This combination poses a significant explosion risk that can be mitigated by reducing the $\mathrm{O}_{2}$ and $\mathrm{H}_{2}$ concentrations in the system to below the explosive threshold $\left(<5 \% \mathrm{H}_{2}\right)$, but this comes at the expense of operating rate. Secondly, many materials are highly permeable to $\mathrm{H}_{2}$ [55], posing both a safety challenge and energy loss mechanism, and may even pose a risk to global climate [56]. While these safety and operational concerns can be assuaged at lab scale, it is unclear if such a system could be reliably deployed at grid-scale at a reasonable cost.

Even if these safety concerns could be circumvented, the low solubility of $\mathrm{H}_{2}$ in water poses a more fundamental challenge $\left(0.0016 \mathrm{~g} / \mathrm{kg} \mathrm{H}_{2} \mathrm{O}\right.$ or $0.8 \mathrm{mM}$ for $\mathrm{H}_{2}$ versus $1.69 \mathrm{~g} / \mathrm{kg} \mathrm{H}_{2} \mathrm{O}$ or $38 \mathrm{mM}$ for $\mathrm{CO}_{2}$ at $20{ }^{\circ} \mathrm{C}$ and $0.1 \mathrm{MPa}$ [57]). A simple model of rewired carbon fixation mediated by $\mathrm{H}_{2}$ diffusion demonstrated that extremely high internal surface areas will be required for full utilization of the current produced by a $1 \mathrm{~m}^{2}$ solar panel [41]. This will likely require some creative engineering to maintain high energy conversion efficiency, minimize losses of $\mathrm{H}_{2}$, maintain acceptable safety, and prevent proton consumption due to fuel synthesis increasing solution $\mathrm{pH}$ to unmanageable levels [41]. While ingenious solutions to this problem do exist, such as the hollow-fiber gas reactor [58], these solutions come at the cost of high manufacturing complexity.

\section{Solid-matrix Extracellular Electron Transfer and Direct Contact}

At the opposite end of the spectrum of biological solutions for long-range electron transport are solid-matrix extracellular electron transfer (SmEET) mechanisms used by electroactive microbes [47]. Note, the widely accepted definition of EET does include soluble mediators like flavins $[59,60]$, but we do not discuss them here. These solid-matrix systems could circumvent the design challenges created by the volatility and low solubility of $\mathrm{H}_{2}$ in water by transferring electrons along conductive nanowires secreted by the cell, or by direct contact of the cell surface with an electrode [61]. 
SmEET involves three parts: long-range transport of electrons often over many cell lengths from an electrode to the cell surface; transfer of electrons from the cell surface to the electron transport chain in the inner membrane; and finally, the production of intracellular reductants that can be used in $\mathrm{CO}_{2}$-fixation or further reduction of partially reduced carbon. Of these three steps, the second, transfer of electrons from the outer to the inner membrane using a membrane-spanning EET complex is perhaps the best understood [62]. To our knowledge there has been only one demonstration of engineered SmEET-mediated rewired carbon fixation to date, in which a $\mathrm{CO}_{2}$-fixing reverse tricarboxylic acid (rTCA) cycle was enabled in the electroactive microbe Geobacter sulfurreducens by the addition of a gene for an ATP-dependent citrate lyase [63]. Despite this breakthrough, at the time of writing, SmEET-mediated rewired carbon fixation systems have yet to achieve the success of $\mathrm{H}_{2}$-mediated systems. Few, if any, organisms have been discovered that can uptake electrons, fix $\mathrm{CO}_{2}$, and meet the needs of the synthetic biology design-build-test loop of rapid heterotrophic growth and facile genetic modification. Furthermore, the formation of biofilms and nanowire secretion do not lend themselves to a short design-build-test loop.

The lack of a suitable naturally occurring chassis organism for SmEET-mediated rewired carbon fixation leaves the option of creating a synthetic chassis by adding SmEET, $\mathrm{CO}_{2}$-fixation and energy storage molecule synthesis to a highly engineerable host like Escherichia coli, Vibrio natriegens, or an organism with a completely synthetic genome. The Shewanella oneidensis Mtr complex [64] and the Calvin cycle [65] have both been separately added to $E$. coli and shown to function, although at a much lower level than in their natural hosts. Getting these systems to operate at their full potential and in concert in a synthetic host will require a much more complete understanding of the physics, chemistry and genetics of SmEET and $\mathrm{CO}_{2}$-fixation.

SmEET can transport electrons between sources and sinks tens to hundreds of microns from the cell surface through microbial nanowires $[47,61]$. These were originally studied for electron transport out of the cell but can also move electrons into the cell. There is considerable debate about the mechanism of charge transfer in nanowires [66, 67].

A redox gradient model of conduction in electroactive biofilms has been championed by Tender, Bond and colleagues and studied most extensively in Geobacter biofilms [68-70], but has recently been studied in mixed community films [71]. This type of conduction relies upon long-range redox diffusion, enabled by short range electron transfer between closely spaced redox cofactors embedded throughout the conductive matrix that is composed of self-assembling protein subunits [72]. The redox gradient model of conduction was established in studies of redox polymers and hydrogels containing redox cofactors [73]. The current-voltage relationships predicted by this model have been successfully used to fit electron transport rate measurements in Geobacter biofilms $[68,74]$. A key experimentally validated prediction of this model is the rise of film conductivity with increasing temperature $[69,70]$.

However, while any one of the large number of multi-heme cytochromes known to be secreted by Geobacter sulfurreducens could be a likely candidate for the redox cofactor used in biofilm conduction, there is no direct structural evidence of inter-heme spacing that is within the short distance $(\approx 10 \AA)$ needed for short range electron hopping needed to support electron transport at the rate seen in isolated nanowires [70]. Consequently, an alternative model for conduction in G. sulfurreducens biofilms has been championed by Malvankar, Tuominen, Lovely and colleagues [70, 75] that relies upon charge delocalization due to pi-stacking interactions in the G. sulfurreducens biofilm, similar to the conduction method in polyaniline. In contrast to the redox gradient model, this model predicts that conductivity should fall with increasing temperature [75]. However, while this predicted result has been observed by Malvankar et al. [75] it has not been seen by other groups [70].

A representative selection of overpotentials for SmEET-mediated systems are shown in Table 2. Given that the redox potential of Mtr EET complex is $\approx-0.1 \mathrm{~V}$ vs. SHE [76, 77], the minimum cell potential in a EET-mediated rewired carbon fixation system with a water-splitting anode is $\approx 1 \mathrm{~V}(-0.1 \mathrm{~V}-0.82 \mathrm{~V})$. The overpotentials shown in Table 2 represent a considerable fraction of this minimum potential difference, suggesting that they could be a significant energy loss mechanism in rewired carbon fixation.

What is the lowest overpotential, or highest biofilm conductivity, that could be achieved? The maximum bulk Geobacter biofilm conductivity observed by Yates et al. was on the order of $5 \times 10^{-6} \mathrm{~S} \mathrm{~cm}^{-1}$ at $30{ }^{\circ} \mathrm{C}$ (a resistivity of $2 \times 10^{5} \Omega \mathrm{cm}$ ) [69]. In contrast, Malvankar et al. report much higher bulk Geobacter biofilm conductivities of $\approx 5$ $\times 10^{-3} \mathrm{~S} \mathrm{~cm}^{-1}\left(2 \times 10^{2} \Omega \mathrm{cm}\right)$ [75]. The source of this discrepancy is unclear. Measurements by El Naggar et al. of dried isolated $S$. oneidensis nanowires indicate a resistivity on the order of only $1 \Omega \mathrm{cm}$ [78]. Calculations by Polizzi et al. suggest that such a low resistivity in a biological material could only be achieved by electron transfer with extremely closely spaced $(\approx 10 \AA)$ redox cofactors, and very low reorganization energies [72].

Gram-negative electroactive microbes have evolved an EET-complex that spans the periplasmic gap and moves electrons between the outer membrane and the electron 
Table 2 Overpotentials for a representative set of biological electron transfer systems

\begin{tabular}{|c|c|c|c|c|c|c|c|c|c|}
\hline Microorganism & Reactions & $\begin{array}{l}\text { Electron } \\
\text { flow }^{\mathrm{a}}\end{array}$ & $\begin{array}{l}\text { Estimated applied } \\
\text { electrode potential } \\
\text { (V. vs. SHE) }\end{array}$ & $\begin{array}{l}\text { Assumed } \\
\text { acceptor }^{\mathrm{b}}\end{array}$ & $\begin{array}{l}\text { Estimated } \\
\text { electrode } \\
\text { overpotential }(V)^{c}\end{array}$ & $\begin{array}{l}\text { Biofilm thickness } \\
(\mu \mathrm{m}) \text { or cell } \\
\text { density (OD unit) }\end{array}$ & $\begin{array}{l}\text { Cathode } \\
\text { material }\end{array}$ & $\begin{array}{l}\text { Electron } \\
\text { transport } \\
\text { mechanism } \\
\end{array}$ & Reference \\
\hline $\begin{array}{l}\text { Geobactor } \\
\text { sulfurreducens } \\
\text { strain } \mathrm{DL}-1\end{array}$ & $\begin{array}{l}\text { Fumarate } \\
\text { to succinate }\end{array}$ & Cathodic & -0.3 & $\begin{array}{l}\text { Mtr EET } \\
\text { Complex }\end{array}$ & $\approx 0.2$ & 35 & Graphite & EET & $\begin{array}{l}\text { Ueki } \\
\text { et al. [63] }\end{array}$ \\
\hline $\begin{array}{l}\text { Geobactor } \\
\text { sulfurreducens }\end{array}$ & $\begin{array}{l}\text { Fumarate } \\
\text { to succinate }\end{array}$ & Cathodic & -0.3 & $\begin{array}{l}\text { Mtr EET } \\
\text { Complex }\end{array}$ & $\approx 0.2$ & 12 & Graphite & EET & $\begin{array}{l}\text { Strycharz- } \\
\text { Glaven } \\
\text { et al. [139] }\end{array}$ \\
\hline $\begin{array}{l}\text { Geobacter } \\
\text { sulfurreducens }\end{array}$ & $\begin{array}{l}\text { Acetate to } \\
\text { electricity }\end{array}$ & Anodic & 0.3 & $\begin{array}{l}\text { Mtr EET } \\
\text { Complex }\end{array}$ & $\approx 0.4$ & 40 & Graphite & EET & $\begin{array}{l}\text { Reguera } \\
\text { et al. [140] }\end{array}$ \\
\hline Sporomusa ovata & $\begin{array}{l}\mathrm{CO}_{2} \text { to } \\
\text { acetate }\end{array}$ & Cathodic & -0.4 & $\begin{array}{l}\text { Mtr EET } \\
\text { Complex }\end{array}$ & $\approx 0.3$ & 12 & Graphite & EET & $\begin{array}{l}\text { Nevin } \\
\text { et al. [141] }\end{array}$ \\
\hline $\begin{array}{l}\text { Mariprofundus } \\
\text { ferrooxydans }\end{array}$ & $\mathrm{Fe}^{3+} / \mathrm{Fe}^{2+}$ & Cathodic & -0.076 & $\begin{array}{l}\text { Mtr EET } \\
\text { Complex }\end{array}$ & - & Initial $O D=0.01$ & Graphite & EET & $\begin{array}{l}\text { Summers } \\
\text { et al. [142] }\end{array}$ \\
\hline $\begin{array}{l}\text { Shewanella } \\
\text { oneidensis MR-1 }\end{array}$ & $\begin{array}{l}\text { Lactate, } \\
\mathrm{Cr}^{+} / \mathrm{Cr}^{6+}\end{array}$ & Anodic & 0.3 & $\begin{array}{l}\text { Mtr EET } \\
\text { Complex }\end{array}$ & - & Initial OD = 0.3 & Graphite & EET & $\begin{array}{l}\text { Xafenias } \\
\text { et al. [143] }\end{array}$ \\
\hline $\begin{array}{l}\text { Acetobacterium } \\
\text { spp }+ \\
\text { Rhodobacteraceae }\end{array}$ & $\begin{array}{l}\mathrm{CO}_{2} \text { to } \\
\text { acetate }\end{array}$ & Cathodic & -0.59 & $\mathrm{H}_{2}$ & $\approx 0.17$ & 0.5 & Graphite & $\mathrm{H}_{2}$ & $\begin{array}{l}\text { Marshall } \\
\text { et al. [144] }\end{array}$ \\
\hline Ralstonia eutropha & $\begin{array}{l}\mathrm{CO}_{2} \text { to } \\
\text { isobutanol }\end{array}$ & Cathodic & -1.4 & $\begin{array}{l}\mathrm{H}_{2} \text { and } \\
\text { Formate }\end{array}$ & $\approx 1$ & Initial $O D=0.8-1$ & $\begin{array}{l}\text { Indium } \\
\text { foil }\end{array}$ & $\begin{array}{l}\mathrm{H}_{2} \text { and } \\
\text { Formate }\end{array}$ & $\begin{array}{l}\mathrm{Li} \\
\text { et al. [43] }\end{array}$ \\
\hline Ralstonia eutropha & $\begin{array}{l}\mathrm{CO}_{2} \text { to } \\
\text { biomass } \\
\text { and } \mathrm{PHB}\end{array}$ & Cathodic & -0.6 & $\mathrm{H}_{2}$ & $\approx 0.2$ & Initial $O D=0.2$ & $\begin{array}{l}\text { Co-P } \\
\text { alloy }\end{array}$ & $\mathrm{H}_{2}$ & $\begin{array}{l}\text { Liu } \\
\text { et al. [45] }\end{array}$ \\
\hline
\end{tabular}

${ }^{a}$ Cathodic electron flow refers to electron flow from cathode to microbial metabolism, whereas anodic flow indicates electron flow from metabolism towards an anode. ${ }^{b}$ and $c$ The electrode overpotential is estimated by subtracting the estimated applied electrode potential from the assumed electron acceptor potential at $\mathrm{pH} 7$ (Mtr EET Complex, E = -0.1 V vs SHE; $\mathrm{H}_{2}, \mathrm{E}=-0.42 \mathrm{~V}$ vs. SHE; Formate, $\mathrm{E}=-0.43 \mathrm{~V}$ vs. SHE). References [43, 45, 63, 139-144] were used to compile this table

transport chain in the inner membrane. This paradigm was first established in the electroactive microbe $S$. oneidensis MR-1, that uses the Mtr EET complex to expel electrons from metabolism onto external substrates like minerals, metal ions and even electrodes in the absence of $\mathrm{O}_{2}$, essentially breathing onto them $[47,79]$. Similar systems containing homologous components also exist in electroactive microbes that specialize in electron uptake from metal oxidation: the phototrophic iron oxidation (Pio) complex in Rhodopseudomonas palustris TIE-1 [80] and Marinobacter subterrani [81]. While $M$. subterrani is readily genetically modifiable, it is not able to fix $\mathrm{CO}_{2}$. On the other hand, $R$. palustris and S. lithotrophicus can both fix $\mathrm{CO}_{2}$, but are not easily genetically modified. To our knowledge, no one has successfully coaxed $S$. lithotrophicus into forming colonies on agar, let alone grown it heterotrophically, or genetically modified it. Furthermore, Ross et al. [82] were able to show that the Mtr complex in S. oneidensis was reversible, allowing cathodically supplied electrons to catalyze the periplasmic reduction of fumarate. Measurement of the redox potentials of the S. oneidensis Mtr EET complex by Firer-Sherwood et al. [76] indicate a potential difference between the outer membrane MtrB cytochrome and the quinone pool of only about $0.0885 \mathrm{~V}$, suggesting that the energy losses in this step could be much lower than in electron transport from the cathode to the cell surface.
Enabling $\mathrm{CO}_{2}$-fixation requires a system for generation of low-potential intracellular reductants with cathodically supplied electrons. In nature, these electrons are typically supplied to autotrophic microbes like S. lithotrophicus by the oxidation of $\mathrm{Fe}(\mathrm{II})$ and $\mathrm{Fe}(\mathrm{II})$-containing minerals. This raises the issue of energetics mismatch: while the redox potential for $\operatorname{NAD}(\mathrm{P})^{+} / \mathrm{NAD}(\mathrm{P}) \mathrm{H}$ is $-0.32 \mathrm{~V}$ vs. SHE [83], the redox potentials of Fe(II) and many Fe-containing minerals at circumneutral $\mathrm{pH}$ are several hundred millivolts higher [77]. While some Fe-oxidizing microbes like $R$. palustris [84] can use light as an additional source of energy to assist in $\operatorname{NAD}(\mathrm{P})^{+}$ reduction, others such as $M$. subterrani [81] and S. lithotrophicus ES-1 [80] are able to draw electrons from the oxidation of iron minerals with no external energy input.

It has long been speculated that autotrophic Fe-oxidizers use reverse electron transport to reduce $\mathrm{NAD}(\mathrm{P})^{+}$[85]. In summary, Fe-oxidizing microbes are thought to use the EET complex to transport electrons across the periplasmic gap and into the quinone pool, at a redox potential of approximately $-0.1 \mathrm{~V}$ vs. SHE [77]. From here the incoming stream of electrons is split into two: one stream is directed downhill in energy toward the reduction of $\mathrm{O}_{2}$, generating a proton gradient across the inner membrane of the cell. This proton motive force is used to generate ATP and raise the energy of the second stream of electrons to enable reduction of $\mathrm{NAD}(\mathrm{P})^{+}$. This process has been called the 
"uphill pathway" [77]. Recently, Rowe et al. [86] provided compelling evidence that cathodically supplied electrons can reduce $\operatorname{NAD}(\mathrm{P})^{+}$in $S$. oneidensis, suggesting that this organism does indeed contain such a pathway.

Should the existence of the uphill pathway in S. oneidensis be confirmed, two immediate questions are raised: what are the components of this pathway, and how is electron flow between the uphill and downhill branches of the pathway regulated? Furthermore, if the components of this pathway could be isolated and used in rewired carbon fixation, what costs does this system impose on overall system efficiency?

\section{Sulfur Transport and Oxidation}

The limitations of hydrogen transport and SmEET have inspired searches for alternative mechanisms of long-range electron transport. Several choices have been proposed that can be renewably sourced including ammonia $\left(\mathrm{NH}_{3}\right)$, phosphite $\left(\mathrm{HPO}_{3}{ }^{-}\right)$, and reduced sulfur compounds $\left(\mathrm{H}_{2} \mathrm{~S}\right.$, $\mathrm{S}_{2} \mathrm{O}_{3}{ }^{2-}, \mathrm{S}_{4} \mathrm{O}_{6}{ }^{2-}$ ) [87]. While ammonia has high solubility in water, its metabolic oxidation product $\mathrm{NO}_{2}^{-}$has high microbial toxicity [87]. Phosphite and its oxidation product phosphate $\left(\mathrm{PO}_{4}{ }^{3-}\right)$ have low toxicity, and both are highly soluble in water. However, the use of phosphite as a redox mediator comes with a potentially large energy loss. The phosphite/phosphate couple has a redox potential of -0.65 $\mathrm{V}$ vs. SHE. However, phosphite directly donates electrons to $\mathrm{NAD}(\mathrm{P})^{+}$through phosphite dehydrogenase, leading to an overpotential loss of over $300 \mathrm{mV}$ [88].

Sulfur can be found in nature in a wide range of oxidation states, from -2 up to 6 , allowing it to carry up to 8 electrons per atom. Each of these oxidation states, except for the most oxidized, can be used as an electron donor for chemoautotrophic microbial growth. The most common sulfur compounds used as electron donors are hydrogen sulfide $\left(\mathrm{H}_{2} \mathrm{~S}\right)$, elemental sulfur $\left(\mathrm{S}^{0}\right)$, tetrathionate $\left(\mathrm{S}_{4} \mathrm{O}_{6}{ }^{2-}\right)$, and thiosulfate $\left(\mathrm{S}_{2} \mathrm{O}_{3}{ }^{2-}\right)$ [89]. Each of these compounds can be microbially oxidized to sulfate $\left(\mathrm{SO}_{4}{ }^{2-}\right)$ [89]. Reduced sulfur compounds (with the exception of $\mathrm{S}^{0}$ ) are far more soluble in water than hydrogen $\left(2.5 \mathrm{~g} / \mathrm{kg} \mathrm{H}_{2} \mathrm{O}\right.$ or $110 \mathrm{mM}$ for $\mathrm{H}_{2} \mathrm{~S}, 1.4 \mathrm{M}$ for $\mathrm{Na}_{2} \mathrm{~S}_{2} \mathrm{O}_{3}$, and $113 \mathrm{mM}$ for $\mathrm{Na}_{2} \mathrm{~S}_{4} \mathrm{O}_{6}$, versus $0.8 \mathrm{mM}$ for $\mathrm{H}_{2}$ at $20{ }^{\circ} \mathrm{C}$ ) [90]. Given that diffusional transfer rate increases with mediator concentration, this has the potential to dramatically increase rates of energy and charge transfer to metabolism, and reduce the internal complexity of the electrosynthesis reactor [41]. As reduced sulfur compounds transfer electrons by diffusion, rather than relying upon a solid matrix, they are suitable for the rapid design-build-test cycle used in synthetic biology. On top of this, hydrogen sulfide, thiosulfate and tetrathionate are far less volatile and flammable than hydrogen, significantly reducing operational safety concerns [91].
It is now possible to electrochemically recycle sulfate, enabling a continuous transfer of electrons to microbial metabolism from a cathode. Bilal and Tributsch demonstrated reduction of sulfate to sulfide on graphite electrode at an applied potential of $1.5 \mathrm{~V}$ vs. SHE, with a bias of $1 \mathrm{~V}$, at temperatures close to $120^{\circ} \mathrm{C}$ [92]. Sulfate can also be directly reduced to tetrathionate at an applied potential of $\approx 1.7 \mathrm{~V}$ vs. SHE on a vitreous carbon electrode $[93,94]$. While electrochemically reducing sulfate directly to thiosulfate is difficult at lab scale due to the high Gibbs free energy of this reaction $(\Delta G \approx 700 \mathrm{~kJ}$ $\mathrm{mol}^{-1}$ ) [95], it is conceivable that this reduction could be catalyzed by multiple reduction steps [96, 97].

Sulfur-oxidizing microbes are often found in the mixing zone between oxygenated seawater and reduced hydrothermal fluids in the vicinity of deep-sea hydrothermal vents. Free-living species including Thiomicrospira and Beggiatoa are found above the seafloor [98], while species like Sulfurimonas are found below it [99]. Amazingly, sulfur-oxidizing microbes are often found inside invertebrates living near hydrothermal vents, providing them with sugar produced directly from carbon dioxide dissolved in the seawater [99-101].

Two pathways for sulfur oxidation are known that enable microorganisms to oxidize reduced sulfur compounds including hydrogen sulfide (Fig. 2), tetrathionate (Fig. 3), and thiosulfate (Fig. 4) to sulfate and use the extracted energy and charge to power chemoautotrophic metabolism. In the Sox (sulfur oxidation) system (Figs. 2a, 3a and 4a), first established in studies of Paracoccus pantotrophus and Sulfurimonas denitrificans, reduced sulfur compounds are immobilized on the SoxY protein and repeatedly oxidized by the SoxCD protein, before final oxidation to sulfate by SoxB $[102,103]$.

The oxidation of reduced sulfur compounds can also occur through a series of non-immobilized intermediates through the full sulfide:quinone oxidoreductase (SQR) pathway (Fig. 2b) or parts of it (Figs. 3b and 4b). When beginning with $\mathrm{H}_{2} \mathrm{~S}$, microorganisms such as Thiobacillus denitreficans and Beggiatoa first use the sulfide:quinone oxidoreductase to oxidize $\mathrm{H}_{2} \mathrm{~S}$ to insoluble elemental sulfur $\left(S^{0}\right)$ that accumulates in the cell's periplasm [104]. When the supply of sulfide has been depleted the stored sulfur is first reduced to $\mathrm{HS}^{-}$by the periplasmic Dissimilatory sulfite reductase (Dsr), followed by a 6-electron oxidation to sulfite at a redox potential of $-0.16 \mathrm{~V}$ vs. SHE by the reverse Dissimilatory sulfite reductase (rDsr) $[89,95]$. Finally, sulfite is oxidized to sulfate with the release of two electrons (Fig. 2b).

The first step of the SQR pathway can be bypassed to enable oxidation of tetrathionate $\left(\mathrm{S}_{4} \mathrm{O}_{6}{ }^{2-}\right)$, and thiosulfate $\left(\mathrm{S}_{2} \mathrm{O}_{3}{ }^{2-}\right)$ (Figs. 3b and $4 \mathrm{~b}$ ). Tetrathionate is first oxidized by Tetrathionate hydrolase (TTH) to sulfate and thioperoxymonosulfate $\left(\mathrm{S}_{3} \mathrm{O}_{3}{ }^{2-}\right)$. Thioperoxymonosulfate 


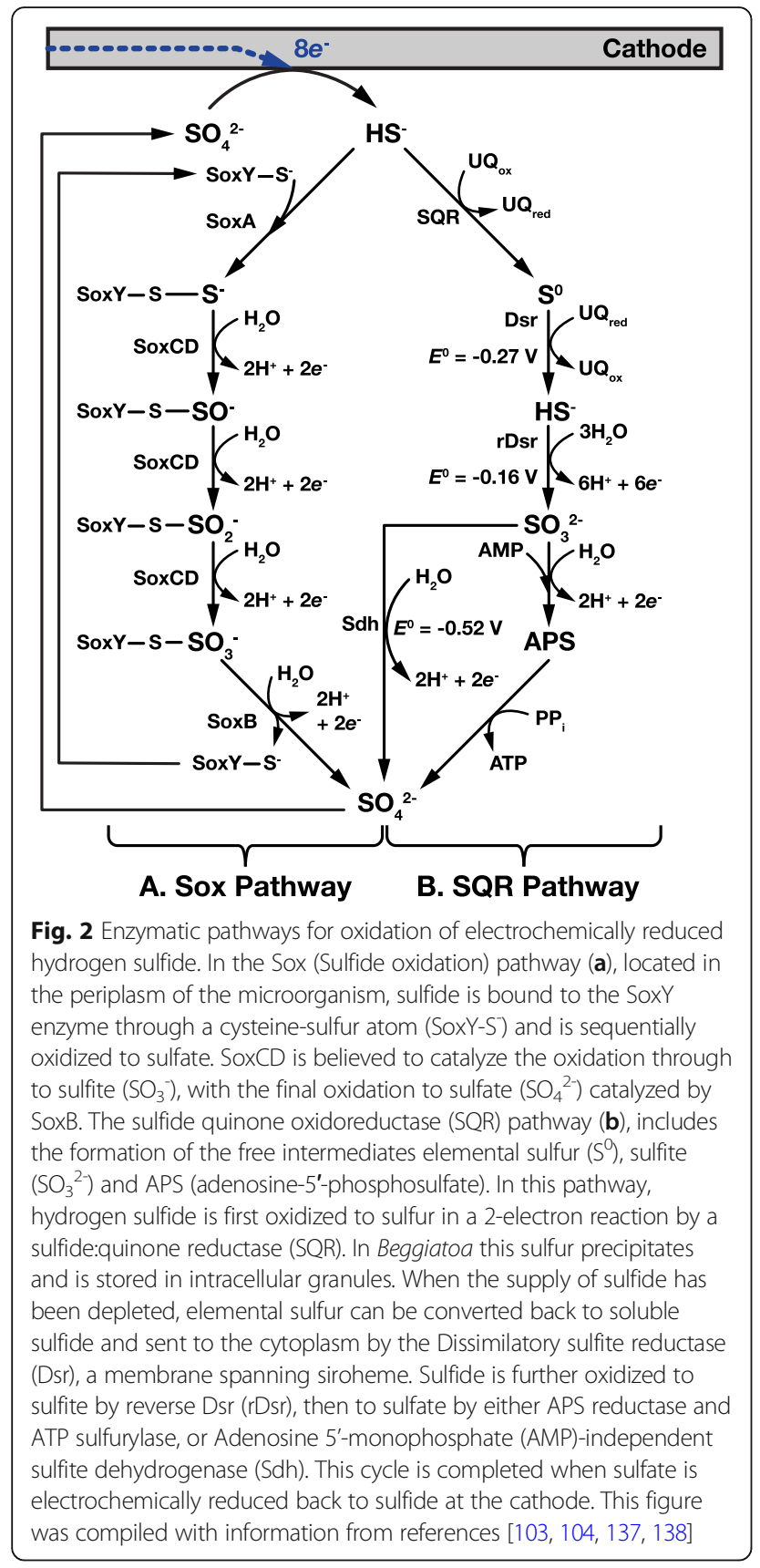

then dissociates to thiosulfate and elemental sulfur that are oxidized by the Sox pathway and post SQR steps of the SQR pathway respectively (Figs. 3a and b).

Thiosulfate is first oxidized by thiosulfate:quinone oxidoreductase (TQO) to tetrathionate which is then then oxidized by TTH to produce sulfate and thioperoxymonosulfate. As before, thioperoxymonosulfate then dissociates to thiosulfate and elemental sulfur that are oxidized by the Sox pathway and post SQR steps of the SQR pathway respectively (Figs. 4a and b).

In all sulfur oxidation pathways, the starting substrates are oxidized to sulfite before final oxidation to sulfate.

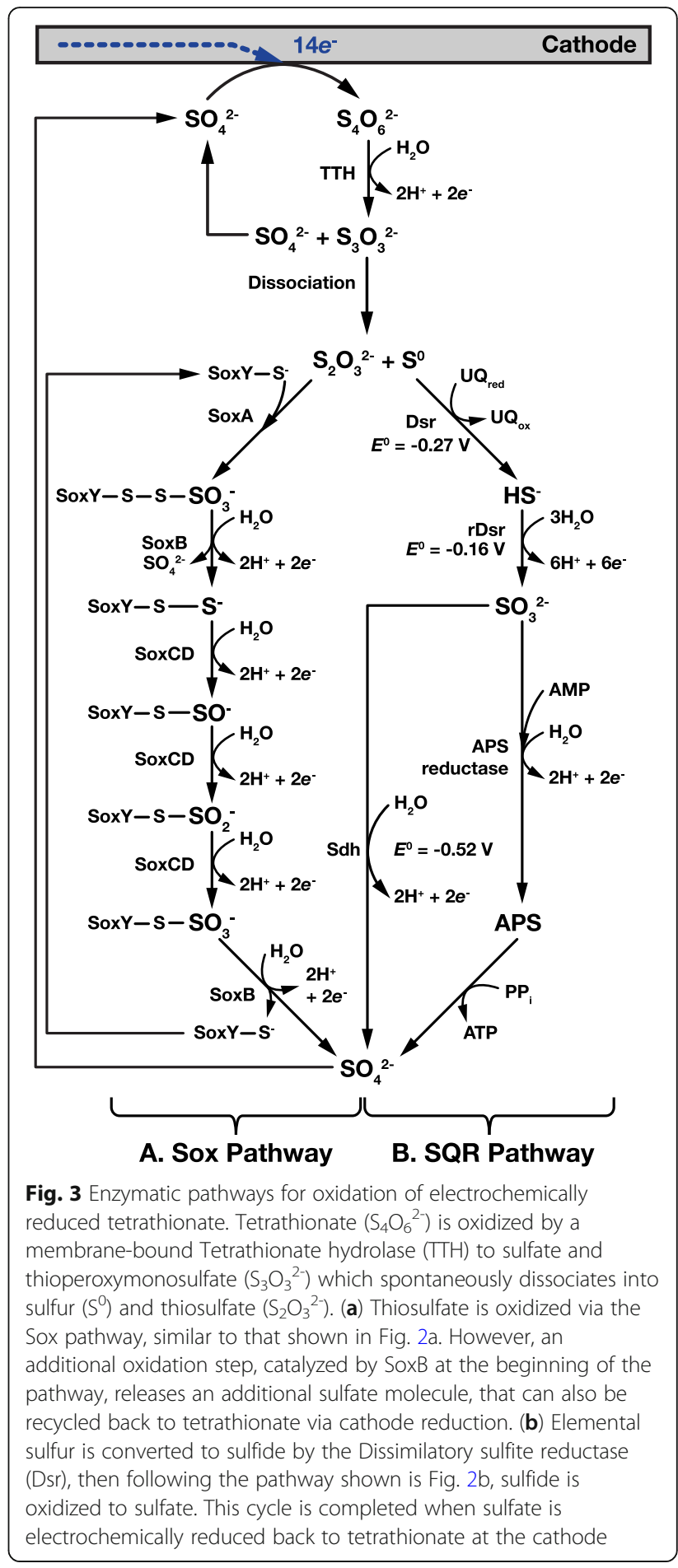

While the reduction potential of sulfite/sulfate is very low ( $\mathrm{E}=-515 \mathrm{mV}$ vs. SHE) [83], at the time of writing, we are unaware of any reports of an enzyme that catalyzes the transfer of electrons from sulfite to $\operatorname{NAD}(\mathrm{P})^{+}$ [87]. Therefore, the microbial utilization of reduced sulfur species is thought to involve reverse electron flow (also known as the uphill pathway). Were sulfur 


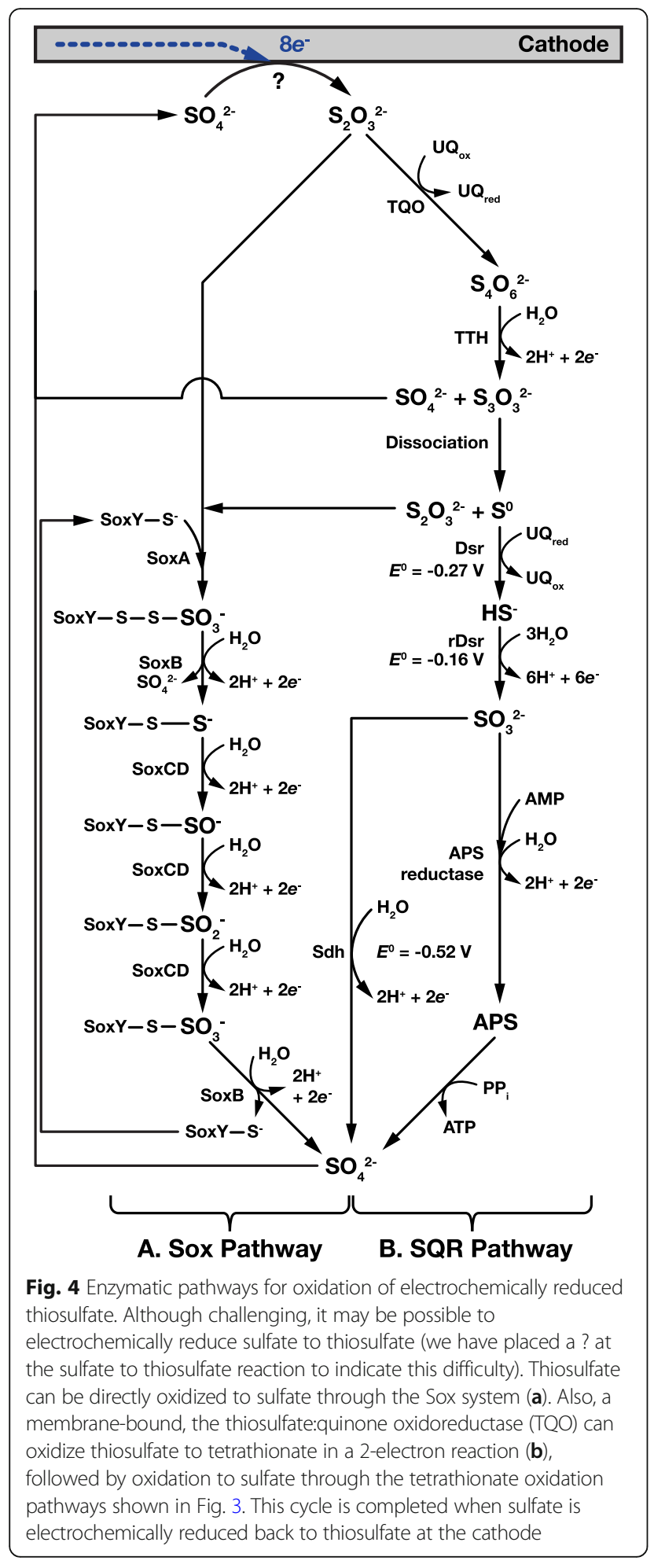

oxidation to be used in rewired carbon fixation, the effect of use of reverse electron flow on the efficiency of the system is unknown. However, use of reverse electron flow does possibly avoid the overpotential losses seen in phosphite oxidation.
In addition to the desirable physicochemical properties of reduced sulfur compounds, this mode of long-range electron transport also comes with biological advantages. Each of the sulfur oxidation pathways presented here are composed of a large number of genes, many of which are known, making reconstitution in heterologous hosts like $E$. coli or $V$. natriegens challenging but almost certainly possible. Furthermore, the large number of organisms that use sulfur-oxidation exist in a wide range of environments with differing $\mathrm{pH}$ and temperature [105]. This gives us a large selection from which to find an easily genetically tractable organism which can be characterized to find the full set of genes needed for sulfur-oxidation and possibly one that meets the needs of the synthetic biology design-test-build loop, and a fully operational rewired carbon fixation system.

\section{Artificial Conductive Matrices}

The limitations of naturally occurring electroactive biofilms both during the prototyping phase of synthetic biology and later during application could be addressed by building artificial conductive matrices tailored for rewired carbon fixation.

Recent works demonstrate that non-biologically synthesized conductive matrices can enhance power output in microbial fuel cells. Yu et al. [106] developed an artificial conductive matrix composed of graphite particles wrapped in conductive polymer chains of polypyrrole. A microbial fuel cell using $S$. oneidensis embedded in this artificial matrix produced 11 times more power than a comparable cell using a natural S. oneidensis biofilm. Estevez-Canales et al. [107] developed an artificial conductive matrix for $G$. sulfurreducens composed of carbon felt fibers embedded in silica gel. The silica-carbon composite allowed rapid encapsulation of G. sulfurreducens, which could allow for rapid prototyping of engineered electroactive microbes in the lab. However, neither of these approaches are amenable to self-assembly and more importantly self-repair, that would allow a rewired carbon fixation system to maintain itself over long periods of time.

Recent advances in the computational design of protein molecules that self-assemble into extended structures open the possibility of creating a synthetic biological conductive matrix. Gonen et al. [108] designed protein homo-oligomers that could self-assemble into $2 \mathrm{D}$ protein arrays with a maximum thickness of 3 to $8 \mathrm{~nm}$, with a maximum length of $1 \mu \mathrm{m}$ [108]. Meanwhile, Shen et al. designed protein monomers that could self-assemble into filaments that were multiple $\mu \mathrm{m}$ in length [109].

A synthetic biological conductive matrix could be engineered to test the competing theories of conduction in natural biofilms and improve upon the conductivity of naturally occurring conductive biofilms in order to 
minimize energetic losses in rewired carbon fixation. One design class could test the redox gradient model of conduction seen in Geobacter biofilms. This class of conductive matrix could be engineered with embedded closely-spaced $(<10 \AA)$ metal ligands [110] that act as redox cofactors to enable long distance redox diffusion. An alternative class of design could test the organic metal model of conduction. This class of design could be engineered to contain aligned pi-stacking interactions to enable charge delocalization. If, as Polizzi et al. speculate [72], the conductivity of individual nanowires is already highly optimized (isolated S. oneidensis nanowires already have a conductivity as high as $1 \mathrm{~S} \mathrm{~cm}^{-1}$ [78]), considerable improvements in bulk conductivity could still be made (G. sulfurreducens films have a conductivity of between $\left(5 \times 10^{-3} \mathrm{~S} \mathrm{~cm}^{-1}[69]\right.$ and $5 \times 10^{-6} \mathrm{~S}$ $\mathrm{cm}^{-1}$ [75]) by increasing the packing density of nanowires in a conductive matrix. Further in the future, it may be possible to design a complementary synthetic conductive matrix and synthetic EET complex with redox potentials well matched to that of $\mathrm{NAD}(\mathrm{P}) \mathrm{H}$, permitting direct reduction without the need of an uphill pathway.

\section{In the Cell Carbon Fixation}

Room temperature and pressure, free-air carbon fixation to carbohydrates and hydrocarbons driven by light-activated water-splitting or from inorganic electron donors like Fe(II), $\mathrm{H}_{2}$, and reduced sulfur compounds is one of the most attractive features of biology. While $R$. eutropha is a highly attractive chassis organism for $\mathrm{H}_{2}$-mediated rewired carbon fixation as it contains both $\mathrm{H}_{2}$-oxidation and $\mathrm{CO}_{2}$-fixation ability, the lack of $\mathrm{CO}_{2}$-fixing ability in many of the most engineerable organisms for rewired carbon fixation, like $E$. coli, $V$. natriegens, and completely synthetic organisms, raises the need to add it. Given a large choice of naturally evolved $\mathrm{CO}_{2}$-fixation pathways and a growing number of proposed and even implemented synthetic alternatives (Table 3), this raises the choice of which one to add.

In an integrated system like natural photosynthesis, where $\mathrm{CO}_{2}$-fixation and light capture are performed in the same cell, the photon supply can exceed the maximum possible photon utilization rate $[41,111]$. This means that given the choice between thermodynamic efficiency and rate of $\mathrm{CO}_{2}$-fixation, evolution will likely trade some efficiency for fixation rate, as there is often an ample supply of photons.

On the other hand, in a separated system like rewired carbon fixation the overall $\mathrm{CO}_{2}$-fixation rate can be increased by connecting more cells. This means that the more efficient the long-range electron transport system is, the more the choice of $\mathrm{CO}_{2}$-fixation method can shift from one that is fast towards one that is thermodynamically efficient.
The most natural first choice of carbon fixation mechanism to engineer into a rewired carbon fixation chassis is the Calvin-Benson-Bassham cycle (CBB; or Calvin cycle) (Table 3). The Calvin cycle is the predominant mode of carbon fixation used in nature and is by far the best characterized. Several attempts of increasing complexity and success have been made at adding part or all of the Calvin cycle to E. coli to transform it into an autotroph. Most recently, Antonovsky et al. [65] demonstrated the synthesis of sugars from fixed carbon with the Calvin Cycle in E. coli, but were unable to accumulate biomass. However, despite these advantages, the Calvin cycle has high ATP and reductant (Ferredoxin and $\operatorname{NAD}(\mathrm{P}) \mathrm{H})$ requirements per substrate molecule, and slow pathway kinetics (Table 3) due mainly to the poor catalytic performance of its carboxylase: $\mathrm{RuBisCO}$. Aside from its slow $\mathrm{CO}_{2}$ fixation rate, $\mathrm{RuBisCO}$ also has an undesirable side-reaction with $\mathrm{O}_{2}$, producing one molecule of glycolate-2-phosphate (G2P) and one molecule of 3-phosphoglycerate, instead of two molecules of 3-phosphoglycerate. Recycling G2P by photorespiration releases $\mathrm{CO}_{2}$ and requires ATP and NADPH. Under current atmospheric $\mathrm{CO}_{2}$ concentrations and at $25{ }^{\circ} \mathrm{C}$, photorespiration raises the minimum quantum requirement of $\mathrm{C}_{3}$ photosynthesis from 8 to 13 photons per $\mathrm{CO}_{2}$ assimilated [112]. It is estimated that up to $30 \%$ of the photosynthetic output is lost through photorespiration [113]. Some organisms that employ the Calvin Cycle minimize energetic losses due to photorespiration by using $\mathrm{CO}_{2}$-concentrating mechanisms such as bundle sheath cells in $\mathrm{C}_{4}$ plants and carboxysomes in cyanobacteria [114].

Given these limitations, other carbon fixation cycles found in nature could be attractive (Table 3). It is conceivable, given recent advances in compartmentalization in synthetic biology $[115,116]$ that highly efficient pathways like the Wood-Ljungdahl pathway that require high $\mathrm{CO}_{2}$ concentrations could be implemented under atmospheric $\mathrm{CO}_{2}$ concentrations in rewired carbon fixation organisms using synthetic carbon concentrating compartments or heterologously expressed carboxysomes [117].

Finally, the limitations of naturally occurring carbon fixation cycles and pathways have led to efforts to design artificial carbon fixation mechanisms with higher kinetic rates and efficiencies than natural mechanisms through new combinations of naturally occurring and synthetic enzymes. A representative set of promising synthetic cycles is shown in Table 3.

Implementing $\mathrm{CO}_{2}$-fixation in a non-native host remains a grand challenge in synthetic biology, but considerable progress has been made in the last decade. Future breakthroughs in this area could be made with better tools for the evolution of autotrophic, $\mathrm{CO}_{2}$-fixing organisms, and better systems biology tools to understand the 


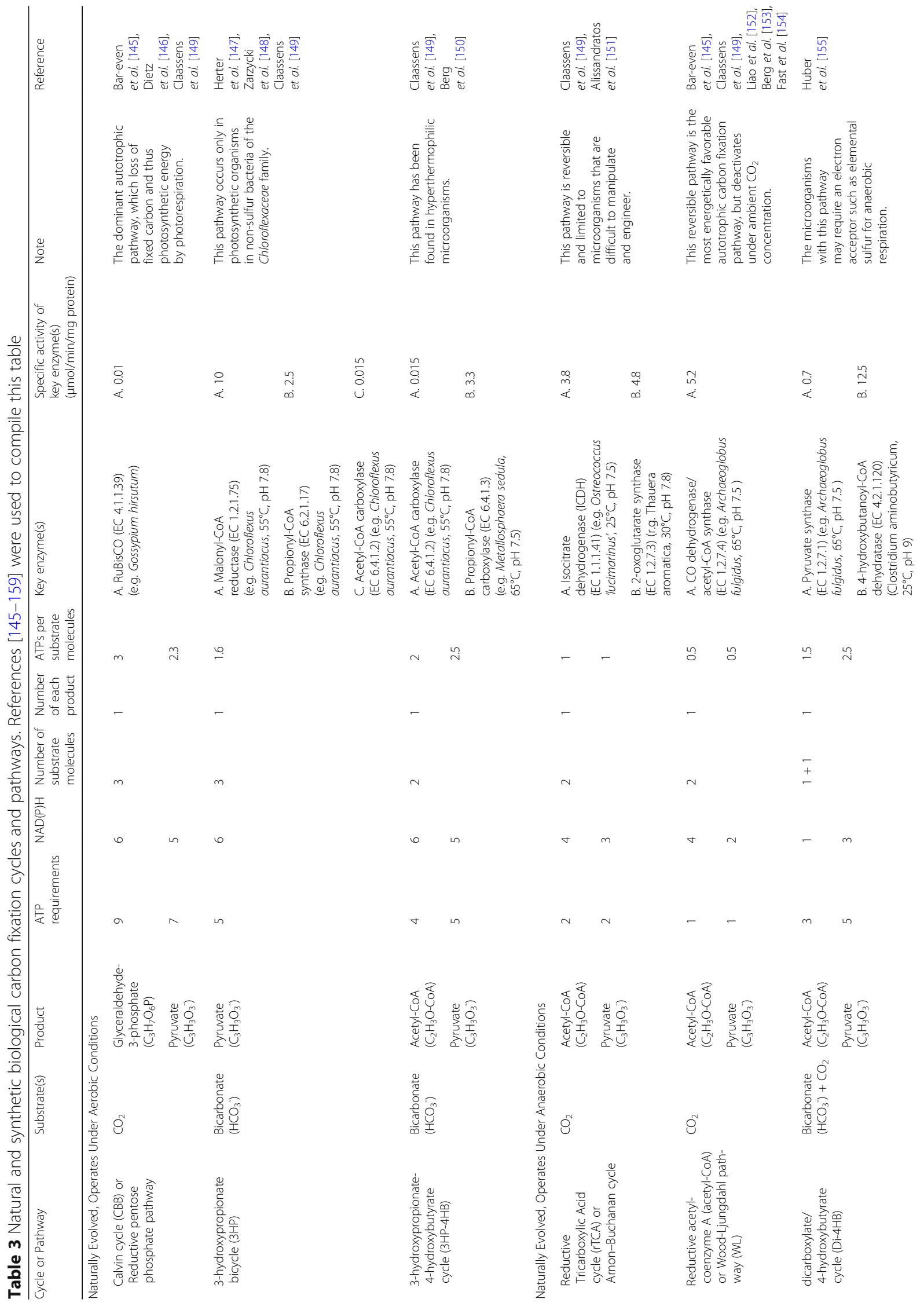




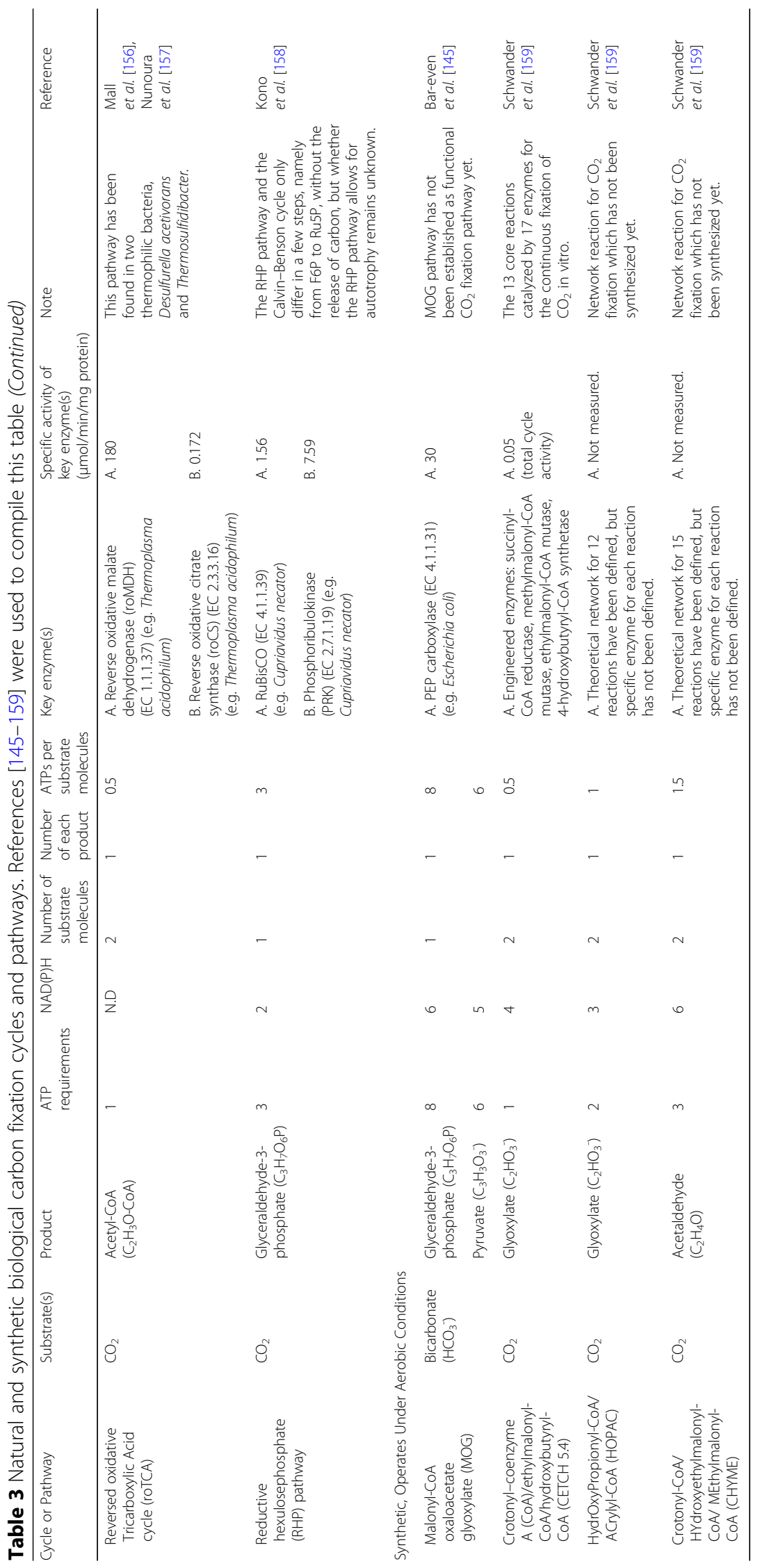


genomes of heteroautotrophs like $R$. eutropha and Chlamydomonas reinhardtii [118].

\section{Out of the Cell Carbon Fixation, Transportation and Uptake \\ Overview}

Recent advances in electrochemistry have enabled the reduction of $\mathrm{CO}_{2}$ to $\mathrm{C}_{1}, \mathrm{C}_{2}$ and $\mathrm{C}_{3}$ compounds (Fig. 1c). A representative set of electrochemical $\mathrm{CO}_{2}$ reductions are shown in Table 4. Electrocatalysts can reduce $\mathrm{CO}_{2}$ to $\mathrm{C}_{1}$ compounds like formate and carbon monoxide with very Faradaic efficiencies and at very high rates [48]. However, the electrochemical production of higher chain length products is much more challenging [119]. Paris et al. [120] recently transformed $\mathrm{CO}_{2}$ into propanol $\left(\mathrm{C}_{3} \mathrm{H}_{8} \mathrm{O}\right)$ with a thin film $\mathrm{Ni}_{3} \mathrm{Al}$ electrode poised at $-1.18 \mathrm{~V}$ vs. SHE but with a Faradaic efficiency of only $1.9 \pm 0.3 \%$ (Table 4). The high efficiencies and rates of electrochemical conversion of $\mathrm{CO}_{2}$ to short chain length products, but the difficulty in conversion to higher molecular weight products, allows a process that was once exclusively performed by biology to be replaced, leaving biology to do what it does exclusively best, the highly efficient synthesis of complex carbon-containing molecules at room temperature and pressure (Figs. 1d and g).

Long-range electron transport and electrochemical $\mathrm{CO}_{2}$ reduction are highly complementary. While microbial metabolism can concatenate and further reduce short chain carbon-containing molecules, this comes with two complications. First, in order to further reduce short chain hydrocarbons (the primary fixation molecule), the release of $\mathrm{CO}_{2}$ is typically required to enable the concentration of the limited number of input electrons. For example, in order to make a single $\mathrm{PHB}$ monomer $\left(\mathrm{C}_{4} \mathrm{H}_{8} \mathrm{O}_{3}\right)$, a microbe would need 42 electrons $\left(n_{e, s}\right.$; where $s$ stands for storage molecule) and 4 carbon atoms $\left(n_{c, s}\right)$. To source these from formate $\left(\mathrm{HCO}_{2}{ }^{-}\right)$ which carries 1 carbon atom $\left(n_{c, p}\right.$; where $p$ stands for primary fixation molecule) and 2 electrons per molecule $\left(n_{e, p}\right.$; where $p$ stands for primary fixation molecule), the microbe would need to expend 21 formate molecules, and then re-emit $17 \mathrm{CO}_{2}$ molecules, a loss of $\approx 80 \%$ of the initially fixed carbon back into the atmosphere. In principle, a carbon-reducing electroactive microbe (Fig. 1d) could simply source the extra electrons $\left(n_{e, a d d}\right)$ to supplement the electrons carried by the primary fixation molecule from long-range electron transport to perform an unbalanced reduction,

$$
n_{e, a d d}=n_{e, s}-\frac{n_{e, p} \times n_{c, s}}{n_{c, p}} .
$$

For instance, with 4 formate molecules, an electroactive microbe could in principle make one PHB monomer by absorbing an additional 34 electrons, with no re-release of carbon back into the atmosphere.

Nature provides a toolkit of enzymes and pathways for processing electrochemically reduced carbon molecules that can potentially work in concert with electron uptake. A summary of a representative set of these pathways is shown in Table 5.

\section{Carbon Monoxide}

Carbon dioxide can be electrochemically reduced to carbon monoxide $(\mathrm{CO})$ at a redox potential of $-0.52 \mathrm{~V}$ vs. SHE at pH 7.0 with extremely high current densities and Faradaic efficiencies as high as 96\% (Table 4). Carbon monoxide dehydrogenase (CODH) catalyzes the reversible oxidation of $\mathrm{CO}$ to $\mathrm{CO}_{2}$, enabling growth on $\mathrm{CO}$ and possibly synthesis of energy storage molecules. Two classes of CODH exist: the first class is found in aerobic microbes such as Oligotropha carboxidovorans [121]: while the second is found in anaerobic microbes including Moorella thermoacetica [122], Rhodospirillum rubrum [123], and Carboxydothermus hydrogenoformans [124].

Despite these attractions, carbon monoxide has a low solubility in water $\left(0.028 \mathrm{~g} / \mathrm{kg} \mathrm{H}_{2} \mathrm{O}\right.$ or $\left.1 \mathrm{mM}\right)$, comparable to that of $\mathrm{H}_{2}(0.8 \mathrm{mM})$, approximately 100 to 1000 times lower than reduced sulfur compounds, and $\approx 45$ times less soluble than $\mathrm{CO}_{2}(45 \mathrm{mM})$ [57, 90]. In addition, electrochemical reduction of $\mathrm{CO}$ with high Faradaic efficiency requires rare metal catalysts ( $\mathrm{Pt}$ and Ir [125]) or nanostructured catalysts [126]. Finally, CO is flammable and highly toxic to both humans and microbes [51, 87]. Taken together, these constraints make $\mathrm{CO}$ far less attractive than reduced sulfur compounds, SmEET or even $\mathrm{H}_{2}$.

\section{Formate and Formic Acid}

Carbon dioxide can be electrochemically reduced to formate $\left(\mathrm{HCO}_{2}{ }^{-}\right)$at high Faradaic efficiency under circumneutral conditions (Table 4). In comparison to other $\mathrm{C}_{1}$ compounds such as methane (-0.24 V vs. SHE at $\mathrm{pH} 7.0)$ and methanol (-0.38 V vs. SHE at $\mathrm{pH} 7.0)$ [119] the low redox potential of formate $(-0.42 \mathrm{~V}$ vs. SHE at $\mathrm{pH} 7.0)$ allows the direct reduction of $\mathrm{NAD}(\mathrm{P})^{+}$.

Furthermore, formate is much more soluble in water (sodium formate has a maximum solubility of $972 \mathrm{~g} / \mathrm{kg}$ $\mathrm{H}_{2} \mathrm{O}$ at $20{ }^{\circ} \mathrm{C}$ or $\left.14.3 \mathrm{M}\right)$ than methane $\left(0.025 \mathrm{~g} / \mathrm{kg} \mathrm{H}_{2} \mathrm{O}\right.$ at $20{ }^{\circ} \mathrm{C}$ or $1.4 \mathrm{mM}$ ) [90]. Li et al. demonstrated the production of isobutanol from electrochemically reduced formate using a synthetic pathway in $R$. eutropha [43]. However, this pathway relies upon the conversion of formate back to $\mathrm{CO}_{2}$ in the cell, forcing this system to be reliant upon the Calvin Cycle and all of its limitations [43]. In addition, there are several naturally occurring formate assimilation pathways that do not rely upon $\mathrm{Ru}$ $\mathrm{BisCO}$, however, at the time of writing there are no 


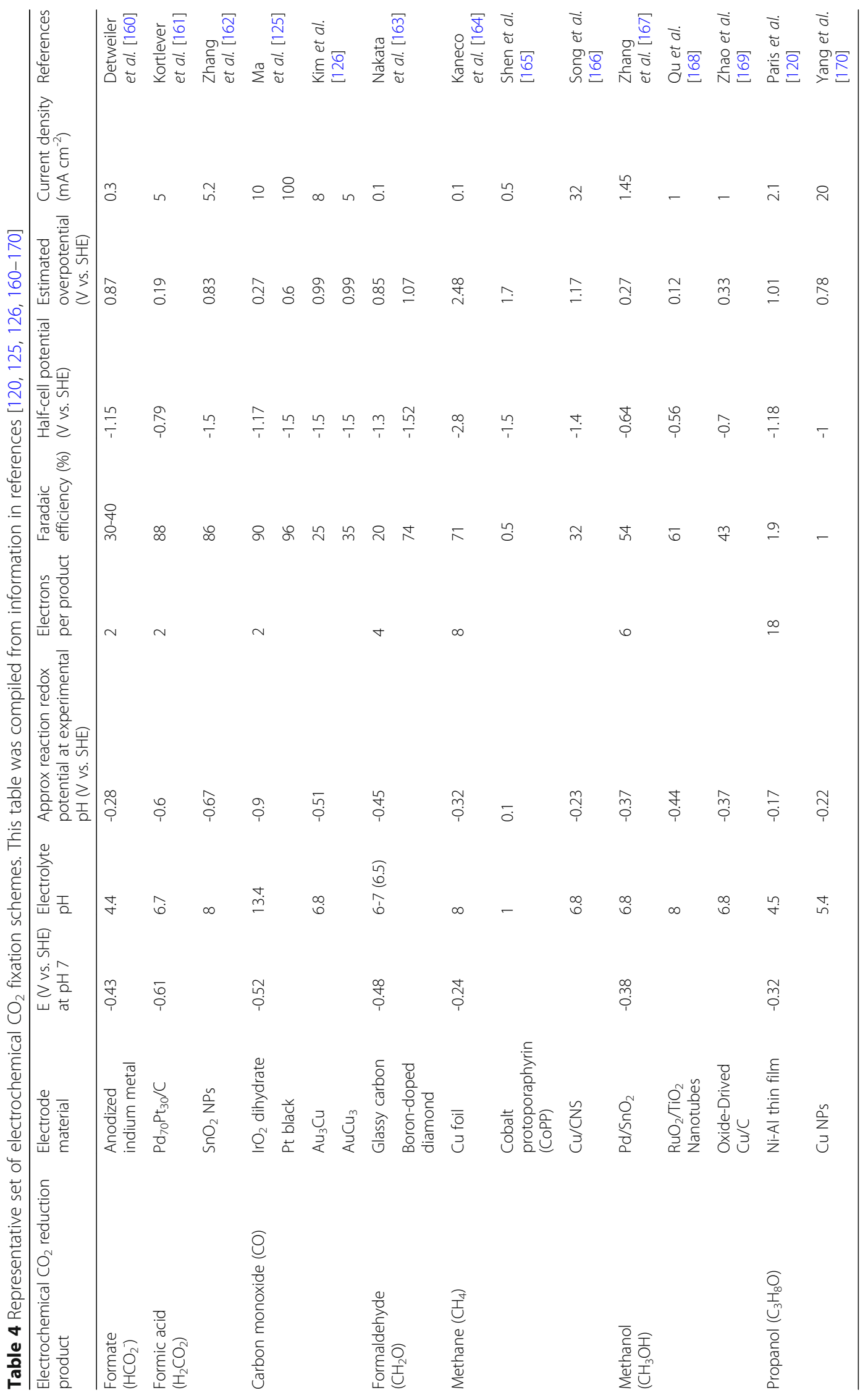




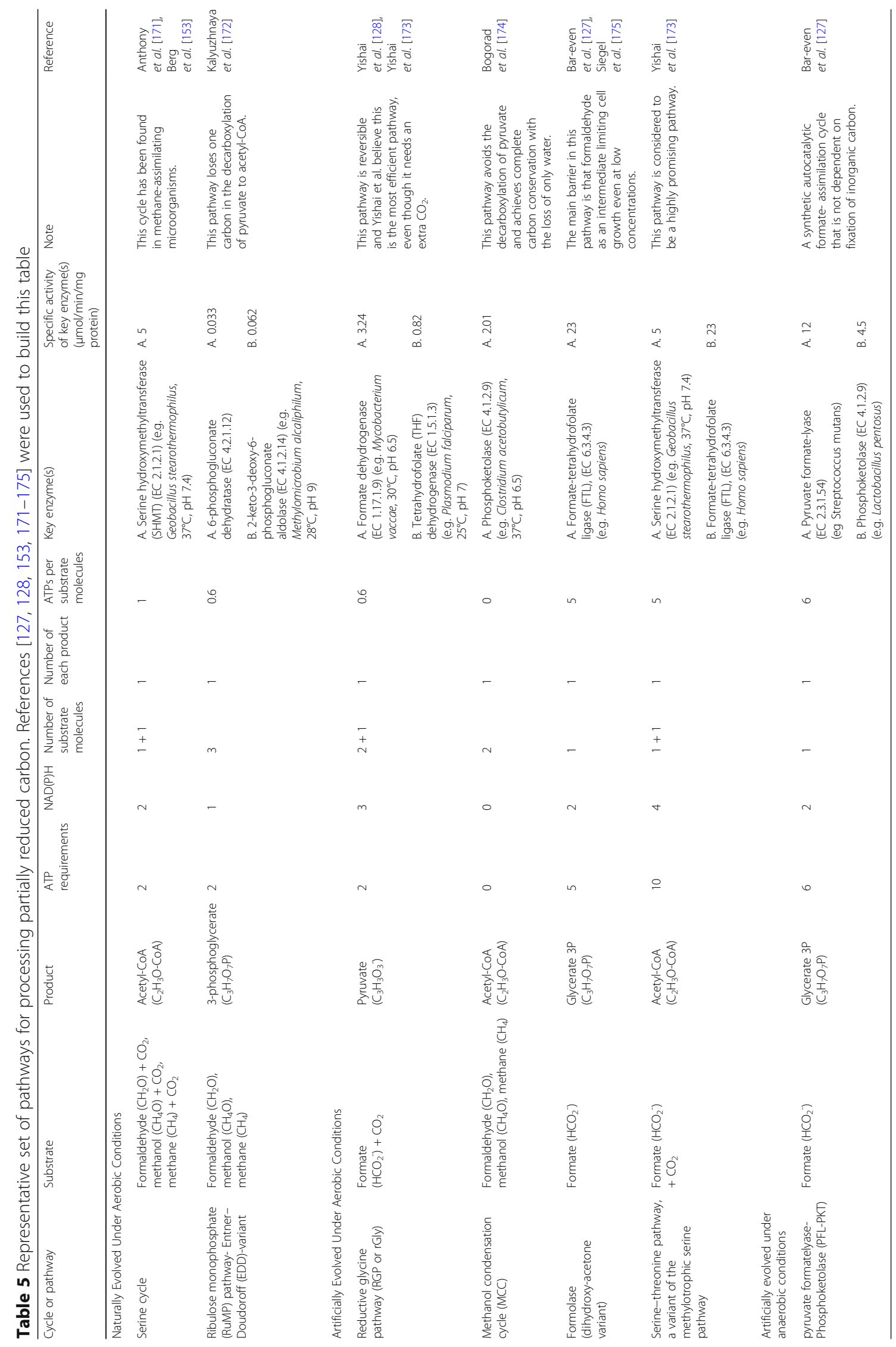


known formate assimilation pathways that do not rely upon the enzymatic incorporation of $\mathrm{CO}_{2}$ [127]. This means that most carbon incorporated into metabolism has to come through enzymatic routes and does not fully leverage the advantages of electrochemical reduction of $\mathrm{CO}_{2}$ to formate. However, recent advances in computational design of synthetic metabolic pathways have yielded several designs that do not rely upon any enzymatic fixation of $\mathrm{CO}_{2}[127,128]$. The most promising are shown in Table 5.

The main barrier to the use of formate as a microbial feed-stock is its toxicity to many of the bacteria that can oxidize it. Formate inhibits growth at concentrations of tens of $\mathrm{mM}$ by inhibiting cytochrome $c$ oxidation [129] and acidifying the cytoplasm, dissipating the proton motive force [130, 131]. A major opportunity in biological engineering is to develop a rewired carbon fixation chassis organism with a higher tolerance to formate, allowing it to take full advantage of the high solubility of both reduced sulfur compounds and formate.

\section{Metabolism and Energy Storage}

At the time of writing, rewired carbon fixation projects have focused on the production and secretion of liquid fuels for transportation. Biology offers a large selection of enzymes and complete metabolic pathways that can produce a large set of fuel molecules at room temperature and pressure including isobutanol [132], octanol [133], branched-chain alcohols [134], medium-chain fatty acids [135], and alkanes [136]. The production of transportation fuels faces several constraints, some of which are set by the physical demands of the application like high energy density and low volatility as in aviation, but also by the need for compatibility with legacy use (think engines and jet turbines), distribution and regulatory infrastructures.

However, far less attention has been paid to the synthesis of carbon-containing molecules that are tailored for the storage and retrieval of electrical energy. As this application is completely new, the constraints of this application can be largely physical in nature: energy density; non-bio-toxicity; non-volatility; and environmental safety. A promising candidate for this role are bio-plastics. Several wild-type $\mathrm{CO}_{2}$ fixing organisms are able to accumulate large quantities of the bioplastic polyhydroxybutyrate (PHB) within the cell. $R$. eutropha is a prolific PHB producer, can accumulate $15 \mathrm{~g}$-PHB per liter of culture per hour when grown on $\mathrm{CO}_{2}, \mathrm{H}_{2}$ and $\mathrm{O}_{2}$, and $\mathrm{PHB}$ can account for up to $87 \%$ of cell weight. Energy could be retrieved from PHB either by metabolic oxidation, and subsequent release of energy directly back to electricity through EET. Alternatively, the accumulated biomass could be gasified, and directedly converted back to electricity in a fuel cell.

\section{Conclusions}

Biology, and particularly rewired carbon fixation, could hold the answer to the large-scale storage of renewable energy. Several key challenges must be addressed: finding a mechanism for long-range electron transport that is efficient, supports high transfer rates, safe, and can be rapidly engineered; a mechanism of carbon fixation that can be expressed in a heterologous host, and is thermodynamically highly efficient, if not also fast; and finally, an energy storage system that is safe, convenient, and enables rapid dispatchibility. These innovations will require breakthroughs in systems biology of non-model exotic microorganisms, mining the genomes of exotic organisms, evolution tools for autotrophic metabolisms and in the development of synthetic enzymes and self-assembling and self-repairing biological nanostructures.

\section{Abbreviations \\ AMP: Adenosine 5'-Monophosphate; APS: Adenosine 5'-Phosphosulfate; Dsr: Dissimilatory sulfite reductase; EET: Extracellular Electron Transfer; EJ: Exajoule ( $1 \times 10^{18}$ Joules); GtC: Gigatonnes of carbon (counting just the mass of carbon atoms in a carbon compound like $\left.\mathrm{CO}_{2}\right)$; GW: Gigawatt $(1 \times$ $10^{9}$ Watts); GWh: Gigawatt-hour (3.6 petajoules); kWh: kilowatt-hour (3.6 megajoules); $n_{c, p}$ : Number of carbons for primary fixation molecule; $n_{c, s}$ : Number of carbons for storage molecule; $n_{e, \text { add }}$ : Number of needed extra electrons; $n_{e, p}$ : Number of electrons for primary fixation molecule; $n_{e, s}$ : Number of electrons for storage molecule; PJ: Petajoule $\left(1 \times 10^{15}\right.$ Joules); rDsr: Reverse Dissimilatory sulfite reductase; SHE: Standard Hydrogen Electrode; SmEET: Solid-matrix Extracellular Electron Transfer; Sox: Sulfur oxidation system; SQR: Sulfide Quinone Oxidoreductase; TQO: Thiosulfate Quinone Oxidoreductase; TTH: Tetrathionate Hydrolase; TW: Terawatt ( $1 \times$ $10^{12}$ Watts); UQ ox: Oxidized Ubiquinone; $U_{\text {red: }}$ Reduced Ubiquinone}

\section{Acknowledgements}

We would like to thank to Alexa Schmitz for critical reading of this manuscript.

\section{Funding}

This work was supported by Cornell University startup funds and a Career Award at the Scientific Interface from the Burroughs-Wellcome Fund to B.B.

\section{Availability of data and materials}

Data sharing is not applicable to this article as no datasets were generated or analyzed during the current study.

Authors' contributions

EAP and BB conceived and outlined this article. FS and BB wrote this article. All authors approved this work.

Ethics approval and consent to participate

Not applicable

Consent for publication

Not applicable

\section{Competing interests}

The authors declare that they have no competing interests.

\section{Publisher's Note}

Springer Nature remains neutral with regard to jurisdictional claims in published maps and institutional affiliations.

\section{Author details}

${ }^{1}$ Department of Biological and Environmental Engineering, Cornell University, Ithaca, NY 14853, USA. ' MultiPHY Laboratories, Inc, Malden, MA 02148, USA. 
Received: 2 April 2019 Accepted: 7 April 2019

\section{Published online: 03 May 2019}

\section{References}

1. Renewable Power Generation Costs in 2017. International Renewable Energy Agency, Abu Dhabi 2018.

2. Cebulla F, Haas J, Eichman J, Nowak W, Mancarella P. How much electrical energy storage do we need? A synthesis for the U.S., Europe, and Germany. Journal of Cleaner Production. 2018;181:449-59.

3. Total electricity end use in the U.S. from 1975 to 2017 (in billion kilowatt hours). [https://www.statista.com/statistics/201794/us-electricityconsumption-since-1975]. Accessed 10 Mar 2019.

4. U.S. Energy Facts. [https://www.eia.gov/energyexplained/?page=us_energy home ]. Accessed 10 Mar 2019.

5. Frew BA, Becker S, Dvorak MJ, Andresen GB, Jacobson MZ. Flexibility mechanisms and pathways to a highly renewable US electricity future. Energy. 2016;101:65-78.

6. Shaner MR, Davis SJ, Lewis NS, Caldeira K. Geophysical constraints on the reliability of solar and wind power in the United States. Energy \& Environmental Science. 2018:11:914-25.

7. Frew BA. Optimizing the integration of renewable energy in the united states. Stanford University, Civil and environmentalEngineering; 2014.

8. World Population Growth. [https://ourworldindata.org/world-populationgrowth]. Accessed 10 Mar 2019.

9. Electricity Explained, Use of electricity. [https://www.eia.gov/ energyexplained/index.php?page=electricity_use]. Accessed 10 Mar 2019.

10. US Energy Storage Market Tops the 1 GWh Milestone in 2017. [https://www. greentechmedia.com/articles/read/us-energy-storage-market-tops-the-gwhmilestone-in-2017\#gs.14qilk]. Accessed 10 Mar 2019.

11. Projected cumulative deployment capacity of energy storage market worldwide from 2015 to 2024 (in gigawatt hours). [https://www.statista. com/statistics/728652/projected-energy-storage-market-capacitydeployment-globally/. Accessed 10 Mar 2019.

12. Spataru C, Kok YC, Barrett M, Sweetnam T. Techno-economic Assessment for Optimal Energy Storage Mix. Energy Procedia. 2015;83:515-24.

13. Edberg $\mathrm{O}$, Naish C. Energy storage and management study. Tech. rep for Scottish gov. AEA Technology PLC. 2010.

14. Luo X, Wang J, Dooner M, Clarke J. Overview of current development in electrical energy storage technologies and the application potential in power system operation. Applied Energy. 2015;137:511-36.

15. Electrical energy storage: white paper. [http://www.iec.ch/whitepaper/pdf/ iecWP-energystorage-LR-en.pdf]. Accessed 10 Mar 2019.

16. MacDonald M, Darling RM. Modeling flow distribution and pressure drop in redox flow batteries. AlChE Journal. 2018;64:3746-55.

17. Beaudin M, Zareipour $\mathrm{H}$, Schellenberglabe A, Rosehart W. Energy storage for mitigating the variability of renewable electricity sources: An updated review. Energy for Sustainable Development. 2010;14:302-14.

18. Armand M, Tarascon J-M. Building better batteries. Nature. 2008;451:652-7.

19. Harry KJ, Hallinan DT, Parkinson DY, MacDowell AA, Balsara NP. Detection of subsurface structures underneath dendrites formed on cycled lithium metal electrodes. Nat Mater. 2014;13:69-73.

20. Kim T, Song W, Son D-Y, Ono LK, Qi Y. Lithium-ion batteries: outlook on present, future, and hybridized technologies. Journal of Materials Chemistry A. 2019

21. Chen H, Cong TN, Yang W, Tan C, Li Y, Ding Y. Progress in electrical energy storage system: A critical review. Progress in Natural Science. 2009:19:291-312.

22. How Much Lithium is in a Li-lon Vehicle Battery? [https://www.linkedin.com/ pulse/how-much-lithium-li-ion-vehicle-battery-paul-martin/]. Accessed 10 Mar 2019.

23. Larcher D, Tarascon JM. Towards greener and more sustainable batteries for electrical energy storage. Nat Chem. 2015;7:19-29.

24. Royston E, Ghosh A, Kofinas P, Harris MT, Culver JN. Self-Assembly of VirusStructured High Surface Area Nanomaterials and Their Application as Battery Electrodes. American Society Chemistry. 2007;24:906-12.

25. Lee YJ, Yi H, Kim W-J, Kang K, Yun DS. Fabricating Genetically Engineered HighPower Lithium-lon Batteries Using Multiple Virus Genes. Science. 2009:324.

26. Li X, Xu H, Chen Z-S, Chen G. Biosynthesis of Nanoparticles by Microorganisms and Their Applications. Journal of Nanomaterials. 2011;2011:1-16.

27. Steger U, Achterberg W, Blok K, Bode H, Frenz W, Gather C, Hanekamp G, Imboden D, Jahnke M, Kost M, Kurz R, Nutzinger HG, Ziesemer T.
Sustainable Development and Innovation in the Energy Sector. Springer Science \& Business Media. 2005.

28. The Middle East, Africa, and Asia now drive nearly all global energy consumption growth. [https://www.eia.gov/todayinenergy/detail.php?id= 37932]. Accessed 10 Mar 2019

29. Slade R, Bauen A, Gross R. Global bioenergy resources. Nature Climate Change. 2014;4:99-105.

30. Lal R. Carbon sequestration. Philos Trans R Soc Lond B Biol Sci. 2008;363: 815-30

31. Foley JA. Net primary productivity in the terrestrial biosphere: The application of a global model. Journal of geophysical research. 1994;99.

32. Falkowski P, Scholes RJ, Boyle E, Canadell J, Canfield D, Elser J, Gruber N, Hibbard K, Högberg P, Linder S, et al. The Global Carbon Cycle: A Test of Our Knowledge of Earth as a System. Science. 2000;290:291-6.

33. Le Quéré $C$, Andrew RM, Friedlingstein $P$, Sitch $S$, Hauck J, Pongratz J, Pickers PA, Korsbakken JI, Peters GP, Canadell JG, et al. Global Carbon Budget 2018. Earth System Science Data. 2018;10:2141-94.

34. Johnston NAC, Blake DR, Rowland FS, Elliott S, Lackner KS, Ziock HJ, Dubey MK, Hanson HP, Barr S. Chemical transport modeling of potential atmospheric CO2 sinks. Energy Conversion and Management. 2003.

35. Brenner MP, Bildsten L, Dyson F, Fortson N, Garwin R, Grober R, Hemley R, Hwa T, Joyce G, Katz J, Koonin S. Engineering microorganisms for energy production: The MITRE Corporation JASON Program Office; 2006.

36. Blankenship RE, Tiede DM, Barber J. Comparing Photosynthetic and Photovoltaic Efficiencies and Recognizing the Potential for Improvement. Science. 2011:332:805-9.

37. Monteith JL. F.R.S: Climate and the efficiency of crop production in Britain Philosophical Transactions of the Royal Society B: Biological Sciences. 1977; 281:277-94.

38. Beale CV, Long SP. Can perennial C4 grasses attain high efficiencies of radiant energy conversion in cool climates? Cell and Environment. 1995;18:641-50.

39. Wijffels B. An outlook on microalgal biofuels. Science. 2010;329:796-9.

40. Zhu XG, Long SP, Ort DR. What is the maximum efficiency with which photosynthesis can convert solar energy into biomass? Curr Opin Biotechnol. 2008;19:153-9.

41. Barstow B. Molecular Mechanisms for the Biological Storage of Renewable Energy. Molecular Mechanisms for the Biological Storage of Renewable Energy; 2015.

42. Adesina O, Anzai IA, Avalos JL, Barstow B. Embracing Biological Solutions to the Sustainable Energy Challenge. Chem. 2017:2:20-51.

43. Li H, Opgenorth PH, Wernick DG, Rogers S, Wu TY, Higashide W, Malati P, Huo YX, Cho KM, Liao JC. Integrated electromicrobial conversion of CO2 to higher alcohols. Science. 2012;335:1596.

44. Torella JP, Gagliardi CJ, Chen JS, Bediako DK, Colón B, Way JC, Silver PA Nocera DG. Efficient solar-to-fuels production from a hybrid microbialwater-splitting catalyst system. Proc Natl Acad Sci U S A. 2015;112:2337-42.

45. Liu C, Colón BC, Ziesack M, Silver PA, Nocera DG. Water splittingbiosynthetic system with $\mathrm{CO} 2$ reduction efficiencies exceeding photosynthesis. Science. 2016:352:1210-3.

46. Nybo SE, Khan NE, Woolston BM, Curtis WR. Metabolic engineering in chemolithoautotrophic hosts for the production of fuels and chemicals. Metab Eng. 2015;30:105-20.

47. Tremblay PL, Angenent LT, Zhang T. Extracellular Electron Uptake: Among Autotrophs and Mediated by Surfaces. Trends Biotechnol. 2017;35:360-71.

48. Martín AJ, Larrazábal GO, Pérez-Ramírez J. Towards sustainable fuels and chemicals through the electrochemical reduction of $\mathrm{CO} 2$ : lessons from water electrolysis. Green Chemistry. 2015;17:5114-30.

49. Kim TS, Kim BH. Electron flow shift in Clostridium acetobutylicum fermentation by electrochemically introduced reducing equivalent. Biotechnology Letters. 1998;10:123-8.

50. Aulenta F, Catervi A, Rossetti S. Electron Transfer from a Solid-State Electrode Assisted by Methyl Viologen Sustains Efficient Microbial Reductive Dechlorination of TCE. Environmental Science \& Technology. 2007:41:2554-9.

51. Toxicology Data Network. [https://toxnet.nlm.nih.gov]. Accessed $10 \mathrm{Mar}$ 2019

52. Greening C, Cook GM. Integration of hydrogenase expression and hydrogen sensing in bacterial cell physiology. Curr Opin Microbiol. 2014;18:30-8.

53. Burgdorf $\mathrm{T}$, Lenz $\mathrm{O}$, Buhrke $\mathrm{T}$, van der Linden $\mathrm{E}$, Jones AK, Albracht SP, Friedrich B. [NiFe]-hydrogenases of Ralstonia eutropha H16: modular enzymes for oxygen-tolerant biological hydrogen oxidation. J Mol Microbiol Biotechnol. 2005;10:181-96. 
54. Volova TG, Kalacheva GS, Altukhova OV. Autotrophic synthesis of polyhydroxyalkanoates by the bacteria Ralstonia eutropha in the presence of carbon monoxide. Appl Microbiol Biotechnol. 2002;58:675-8.

55. Steward SA. Review of Hydrogen Isotope Permeability Through Materials. Livermore: Lawrence Livermore National Lab. (LLNL); 1983.

56. Tromp TK. Run-Lie Shia, Mark Allen, John M. Eiler, Yung YL: Potential Environmental Impact of a Hydrogen Economy on the Stratosphere. Science. 2003;300:1740-2.

57. Solubility of Gases in Water. [https://www.engineeringtoolbox.com/gasessolubility-water-d_1148.html]. Accessed 10 Mar 2019.

58. Worden RM, Liu YC: Catalytic bioreactors and methodes of using same. (Patents G ed., vol. US2014/018782.6A1; 2014.

59. Kracke F, Vassilev I, Kromer JO. Microbial electron transport and energy conservation - the foundation for optimizing bioelectrochemical systems. Front Microbiol. 2015;6:575

60. Light SH, Su L, Rivera-Lugo R, Cornejo JA, Louie A, lavarone AT, Ajo-Franklin CM, Portnoy DA. A flavin-based extracellular electron transfer mechanism in diverse Gram-positive bacteria. Nature. 2018;562:140-4.

61. Reguera G, McCarthy KD, Mehta T, Nicoll JS, Tuominen MT, Lovley DR. Extracellular electron transfer via microbial nanowires. Nature. 2005;435: 1098-101.

62. Rabaey K, Rozendal RA. Microbial electrosynthesis - revisiting the electrical route for microbial production. Nat Rev Microbiol. 2010;8:706-16.

63. Ueki T, Nevin KP, Woodard TL, Aklujkar MA, Holmes DE, Lovley DR Construction of a Geobacter Strain With Exceptional Growth on Cathodes. Front Microbiol. 2018;9:1512.

64. TerAvest MA, Zajdel TJ, Ajo-Franklin CM. The Mtr Pathway of Shewanella oneidensis MR-1 Couples Substrate Utilization to Current Production in Escherichia coli. ChemElectroChem. 2014;1:1874-9.

65. Antonovsky N, Gleizer S, Noor E, Zohar Y, Herz E, Barenholz U, Zelcbuch L, Amram S, Wides A, Tepper N, et al. Sugar Synthesis from CO2 in Escherichia coli. Cell. 2016;166:115-25.

66. Malvankar NS, Tuominen MT, Lovley DR: Comment on "On electrical conductivity of microbial nanowires and biofilms" by S. M. Strycharz-Glaven, R. M. Snider, A. Guiseppi-Elie and L. M. Tender, Energy Environ. Sci., 2011, 4, 4366. Energy \& Environmental Science 2012, 5.

67. Strycharz-Glaven SM, Tender LM. Reply to the 'Comment on "On electrical conductivity of microbial nanowires and biofilms"' by N. S. Malvankar, M. T. Tuominen and D. R. Lovley. Energy Environ. Sci. 2012;5 https://doi.org/10. 1039/c2ee02613a.

68. Snider RM, Strycharz-Glaven SM, Tsoi SD, Erickson JS, Tender LM. Longrange electron transport in Geobacter sulfurreducens biofilms is redox gradient-driven. Proc Natl Acad Sci U S A. 2012;109:15467-72.

69. Yates MD, Golden JP, Roy J, Strycharz-Glaven SM, Tsoi S, Erickson JS, El-Naggar MY, Calabrese Barton S, Tender LM. Thermally activated long range electron transport in living biofilms. Phys Chem Chem Phys. 2015;17:32564-70.

70. Boyd DA, Snider RM, Erickson JS, Roy JN, Strycharz-Glaven SM, Tender LM. Theory of Redox Conduction and The Measurement of Electron Transport Rates Through Electrochemically Active Biofilms. In Biofilms in bioelectrochemical systems. Edited by Beyenal H, Babauta JT. Wiley. 2015: 177-209.

71. Yates MD, Barr Engel S, Eddie BJ, Lebedev N, Malanoski AP, Tender LM. Redox-gradient driven electron transport in a mixed community anodic biofilm. FEMS Microbiol Ecol. 2018:94.

72. Polizzi NF, Skourtis SS, Beratan DN. Physical constraints on charge transport through bacterial nanowires. Faraday Discuss. 2012;155:43-61.

73. Forster RJ, Walsh DA, Mano N, Mao F, Heller A. Modulating the Redox Properties of an Osmium-Containing Metallopolymer through the Supporting Electrolyte and Cross-Linking. American Chemical Society. 2004;20:862-8.

74. Strycharz-Glaven SM, Snider RM, Guiseppi-Elie A, Tender LM. On the electrical conductivity of microbial nanowires and biofilms. Energy \& Environmental Science. 2011;4.

75. Malvankar NS, Lovley DR. Electronic Conductivity in Living Biofilms: Physical Meaning, Mechanisms, and Measurement Methods. In Biofilms in bioelectrochemical systems. Edited by Beyenal H, Babauta JT. Wiley. 2015:211-47.

76. Firer-Sherwood M, Pulcu GS, Elliott SJ. Electrochemical interrogations of the Mtr cytochromes from Shewanella: opening a potential window. J Biol Inorg Chem. 2008;13:849-54.

77. Bird LJ, Bonnefoy $V$, Newman DK. Bioenergetic challenges of microbial iron metabolisms. Trends Microbiol. 2011;19:330-40.
78. El-Naggar MY, Wanger G, Leung KM, Yuzvinsky TD, Southam G, Yang J, Lau WM, Nealson KH, Gorby YA. Electrical transport along bacterial nanowires from Shewanella oneidensis MR-1. Proc Natl Acad Sci U S A. 2010;107:18127-31.

79. Shi L, Rosso KM, Clarke TA, Richardson DJ, Zachara JM, Fredrickson JK. Molecular Underpinnings of Fe (III) Oxide Reduction by Shewanella Oneidensis MR-1. Front Microbiol. 2012;3:50.

80. Liu J, Wang Z, Belchik SM, Edwards MJ, Liu C, Kennedy DW, Merkley ED, Lipton MS, Butt JN, Richardson DJ, et al. Identification and Characterization of MtoA: A Decaheme c-Type Cytochrome of the Neutrophilic Fe(II)-Oxidizing Bacterium Sideroxydans lithotrophicus ES-1. Front Microbiol. 2012;3:37.

81. Bonis BM, Gralnick JA. Marinobacter subterrani, a genetically tractable neutrophilic Fe(II)-oxidizing strain isolated from the Soudan Iron Mine. Front Microbiol. 2015:6:719.

82. Ross DE, Flynn JM, Baron DB, Gralnick JA, Bond DR. Towards electrosynthesis in shewanella: energetics of reversing the mtr pathway for reductive metabolism. PLoS One. 2011;6:e16649.

83. Thauer RK, Jungermann K, Decker K. Energy conservation in chemotrophic anaerobic bacteria. American Society of Microbiology. 1997;41:100-180.

84. Jiao Y, Newman DK. The pio operon is essential for phototrophic Fe(II) oxidation in Rhodopseudomonas palustris TIE-1. J Bacteriol. 2007;189:1765-73.

85. Richardson DJ, Butt JN, Fredrickson JK, Zachara JM, Shi L, Edwards MJ, White G, Baiden N, Gates AJ, Marritt SJ, Clarke TA. The 'porin-cytochrome' model for microbe-to-mineral electron transfer. Mol Microbiol. 2012;85:201-12.

86. Rowe AR, Rajeev P, Jain A, Pirbadian S, Okamoto A, Gralnick JA, El-Naggar MY, Nealson KH. Tracking Electron Uptake from a Cathode into Shewanella Cells: Implications for Energy Acquisition from Solid-Substrate Electron Donors. MBio. 2018;9.

87. Claassens NJ, Sanchez-Andrea I, Sousa DZ, Bar-Even A. Towards sustainable feedstocks: A guide to electron donors for microbial carbon fixation. Curr Opin Biotechnol. 2018:50:195-205.

88. Relyea HA, van der Donk WA. Mechanism and applications of phosphite dehydrogenase. Bioorg Chem. 2005;33:171-89.

89. Madigan MT, Martinko JM, unlap PVD, Clark DP. Metabolic Diversity of Microorganisms. In: Brock biology of Microorganisms; 2009. p. 403-590.

90. U.S. National Library of Medicine. [https://pubchem.ncbi.nlm.nih.gov]. Accessed 10 Mar 2019.

91. CAMEO chemicals, Database of Hazardous Materials. [https:// cameochemicals.noaa.gov]. Accessed 10 Mar 2019.

92. bilal BA, Tributsch $\mathrm{H}$. Thermo-electrochemical reduction of sulfate to sulfide using a graphite cathode. Journal of Applied Electrochemistry. 1998;28: 1073-81.

93. Feng J, Johnson DC. Oxidation of Thiosulfate to Sulfate at Glassy Carbon Electrodes. Electrochemical Society. 1995;142:2618-20.

94. Kish JR, Ives MB. A thermodynamic rationalisation for the oxidising behaviour of concentrated H2SO4. The Canadian Journal of Chemical Engineering. 2011;89:1311-9.

95. Kelly DP. Thermodynamic aspects of energy conservation by chemolithotrophic sulfur bacteria in relation to the sulfur oxidation pathways. Arch Microbiol. 1999:171:219-29.

96. Zelinsky AG. RDE study of thiosulfate oxidation on gold. Journal of Electroanalytical Chemistry. 2014;735:111-4.

97. Zelinsky AG. Anode current on gold in mixed thiosulfate-sulfite electrolytes. Electrochimica Acta. 2015:154:315-20.

98. Teske A, Nelson DC. The Genera Beggiatoa and Thioploca. In: Dworkin M, Falkow S, Rosenberg E, Schleifer K-H, Stackebrandt E, editors. The Prokaryotes: A Handbook on the Biology of Bacteria; 2006. p. 784-810.

99. Campbell BJ, Engel AS, Porter ML, Takai K. The versatile epsilonproteobacteria: key players in sulphidic habitats. Nat Rev Microbiol. 2006;4: 458-68.

100. Haddad A, Camacho F, Durand P, Cary SC. Phylogenetic Characterization of the Epibiotic Bacteria Associated with the Hydrothermal Vent Polychaete Alvinella pompejana. Applied and environmental microbiology. 1995;61: 1679-87.

101. Sievert SM, Hügler M, Taylor CD, Wirsen CO. Sulfur Oxidation at Deep-Sea Hydrothermal Vents. In: Dahl C, Friedrich CG, editors. Microbial Sulfur Metabolism: Springer; 2008.

102. Friedrich CG, Rother D, Bardischewsky F, Quentmeier A, Fischer J. Oxidation of reduced inorganic sulfur compounds by bacteria: emergence of a common mechanism. Appl Environ Microbiol. 2001;67:2873-82.

103. Friedrich C g, AQ HP. Novel Genes Coding for Lithotrophic Sulfur Oxidation of Paracoccus pantotrophus GB17. Journal of Bacteriology. 2000;182:4677-87. 
104. Poser A, Vogt C, Knoller K, Ahlheim J, Weiss H, Kleinsteuber S, Richnow HH. Stable sulfur and oxygen isotope fractionation of anoxic sulfide oxidation by two different enzymatic pathways. Environ Sci Technol. 2014;48:9094-102.

105. Ghosh W, Dam B. Biochemistry and molecular biology of lithotrophic sulfur oxidation by taxonomically and ecologically diverse bacteria and archaea. FEMS Microbiol Rev. 2009;33:999-1043.

106. Yu YY, Chen HL, Yong YC, Kim DH, Song H. Conductive artificial biofilm dramatically enhances bioelectricity production in Shewanella-inoculated microbial fuel cells. Chemical Communications. 2011;47:12825-7.

107. Estevez-Canales M, Pinto D, Coradin T, Laberty-Robert C, Esteve-Nunez A. Silica immobilization of Geobacter sulfurreducens for constructing ready-touse artificial bioelectrodes. Microb Biotechnol. 2018;11:39-49.

108. Gonen S, DiMaio F, Gonen T, Baker D. Design of ordered two-dimensional arrays mediated by noncovalent protein-protein interfaces; 2015.

109. Shen HFJ, Lynch E, Sheffler W, Parry B, Jannetty N, Decarreau J, Wagenbach M, Vicente JJ, Chen J, Wang L, Baker D. De novo design of self-assembling helical protein filaments. Science. 2018;362:705-9.

110. Mills JH, Khare SD, Bolduc JM, Forouhar F, Mulligan VK, Lew S, Seetharaman J, Tong L, Stoddard BL, Baker D. Computational design of an unnatural amino acid dependent metalloprotein with atomic level accuracy. J Am Chem Soc. 2013:135:13393-9.

111. Ooms MD, Dinh CT, Sargent EH, Sinton D. Photon management for augmented photosynthesis. Nat Commun. 2016;7:12699.

112. Zhu XG, Long SP, Ort DR. Improving photosynthetic efficiency for greater yield. Annu Rev Plant Biol. 2010;61:235-61.

113. Walker BJ, VanLoocke A, Bernacchi CJ, Ort DR. The Costs of Photorespiration to Food Production Now and in the Future. Annu Rev Plant Biol. 2016;67:107-29.

114. Rae BD, Long BM, Whitehead LF, Forster B, Badger MR, Price GD. Cyanobacterial carboxysomes: microcompartments that facilitate $\mathrm{CO} 2$ fixation. J Mol Microbiol Biotechnol. 2013:23:300-7.

115. Polka JK, Silver PA. A Tunable Protein Piston That Breaks Membranes to Release Encapsulated Cargo. ACS Synth Biol. 2016;5:303-11.

116. Butterfield GL, Lajoie MJ, Gustafson HH, Sellers DL, Nattermann U, Ellis D, Bale JB, Ke S, Lenz GH, Yehdego A, et al. Evolution of a designed protein assembly encapsulating its own RNA genome. Nature. 2017:552:415-20.

117. Long BM, Hee WY, Sharwood RE, Rae BD, Kaines S, Lim YL, Nguyen ND, Massey B, Bala S, von Caemmerer S, et al. Carboxysome encapsulation of the CO2fixing enzyme Rubisco in tobacco chloroplasts. Nat Commun. 2018;9:3570.

118. Li X, Zhang R, Patena W, Gang SS, Blum SR, Ivanova N, Yue R, Robertson JM, Lefebvre PA, Fitz-Gibbon ST, et al. An Indexed, Mapped Mutant Library Enables Reverse Genetics Studies of Biological Processes in Chlamydomonas reinhardtii. Plant Cell. 2016;28:367-87.

119. Zhang W, Hu Y, Ma L, Zhu G, Wang Y, Xue X, Chen R, Yang S, Jin Z. Progress and Perspective of Electrocatalytic CO2 Reduction for Renewable Carbonaceous Fuels and Chemicals. Advanced Science. 2018:5:1700275.

120. Paris AR, Bocarsly AB. Ni-Al Films on Glassy Carbon Electrodes Generate an Array of Oxygenated Organics from CO2. ACS Catalysis. 2017;7:6815-20.

121. Zhang B, Hemann CF, Hille R. Kinetic and spectroscopic studies of the molybdenum-copper CO dehydrogenase from Oligotropha carboxidovorans. J Biol Chem. 2010;285:12571-8.

122. Appel AM, Bercaw JE, Bocarsly AB, Dobbek H, DuBois DL, Dupuis M, Ferry JG Fujita E, Hille R, Kenis PJ, et al. Frontiers, opportunities, and challenges in biochemical and chemical catalysis of CO2 fixation. Chem Rev. 2013:113:6621-58.

123. Bonam D, Ludden P. Purification and Characterization of Carbon Monoxide Dehydrogenase, a Nickel, Zinc, Iron-Sulfur Protein, from Rhodospirillum rubrum. Journal of Biological Chemistry. 1987;262:2980-7.

124. Svetlitchnyi V, Peschel C, Acker G, Meyer O. Two Membrane-Associated NiFeS-Carbon Monoxide Dehydrogenases from the Anaerobic CarbonMonoxide-Utilizing Eubacterium Carboxydothermus hydrogenoformans. Journal of Bacteriology. 2001;183:5134-44.

125. Ma S, Luo R, Moniri S, Lan Y, Kenis PJA. Efficient Electrochemical Flow System with Improved Anode for the Conversion of CO2 to CO. Journal of The Electrochemical Society. 2014;161:F1124-31.

126. Kim D, Resasco J, Yu Y, Asiri AM, Yang P. Synergistic geometric and electronic effects for electrochemical reduction of carbon dioxide using gold-copper bimetallic nanoparticles. Nat Commun. 2014;5:4948.

127. Bar-Even A. Formate Assimilation: The Metabolic Architecture of Natural and Synthetic Pathways. Biochemistry. 2016;55:3851-63.

128. Yishai O, Bouzon M, Doring V, Bar-Even A. In Vivo Assimilation of OneCarbon via a Synthetic Reductive Glycine Pathway in Escherichia coli. ACS Synth Biol. 2018;7:2023-8.
129. Nicholls P. Formate as an inhibitor of cytochrome coxidase. In: Biochemical and biophysical research comminications 1975, vol. 67. p. 610-6.

130. Warnecke T, Gill RT. Organic acid toxicity, tolerance, and production in Escherichia coli biorefining applications. Microb Cell Fact. 2005;4:25.

131. Yishai O, Lindner SN, Gonzalez de la Cruz J, Tenenboim H, Bar-Even A. The formate bio-economy. Curr Opin Chem Biol. 2016;35:1-9.

132. Atsumi S, Higashide W, Liao JC. Direct photosynthetic recycling of carbon dioxide to isobutyraldehyde. Nat Biotechnol. 2009;27:1177-80.

133. Foo JL, Leong SSJ. Directed evolution of an E. coli inner membrane transporter for improved efflux of biofuel molecules; 2013.

134. Lu J, Brigham CJ, Gai CS, Sinskey AJ. Studies on the production of branched-chain alcohols in engineered Ralstonia eutropha. Appl Microbiol Biotechnol. 2012:96:283-97.

135. Nobuhiro Ishida, Satoshi Saitoh, Toru Onishi, Kenro Tokuhiro, Eiji Nagamori, Katsuhiko Kitamoto, Takahashi. H: The Effect of Pyruvate Decarboxylase Gene Knockout in Saccharomyces cerevisiae on L-Lactic Acid Production. Biosci Biotechnol Biochem 2006, 70:1148-1153.

136. Schirmer A, Rude MA, Li X, Popova E, SBd C. Microbial Biosynthesis of Alkanes. Science. 2010;329:559-62.

137. Beller HR, Chain PS, Letain TE, Chakicherla A, Larimer FW, Richardson PM, Coleman MA, Wood AP, Kelly DP. The genome sequence of the obligately chemolithoautotrophic, facultatively anaerobic bacterium Thiobacillus denitrificans. J Bacteriol. 2006;188:1473-88.

138. Harada M, Yoshida T, Kuwahara H, Shimamura S, Takaki Y, Kato C, Miwa T, Miyake $H$, Maruyama T. Expression of genes for sulfur oxidation in the intracellular chemoautotrophic symbiont of the deep-sea bivalve Calyptogena okutanii. Extremophiles. 2009;13:895-903.

139. Strycharz SM, Woodard TL, Johnson JP, Nevin KP, Sanford RA, Loffler FE, Lovley DR. Graphite electrode as a sole electron donor for reductive dechlorination of tetrachlorethene by Geobacter lovleyi. Appl Environ Microbiol. 2008;74:5943-7.

140. Reguera G, Nevin KP, Nicoll JS, Covalla SF, Woodard TL, Lovley DR. Biofilm and nanowire production leads to increased current in Geobacter sulfurreducens fuel cells. Appl Environ Microbiol. 2006;72:7345-8

141. Nevin KP, Woodard TL, Franks AE, Summers ZM, Lovley DR. Microbial electrosynthesis: feeding microbes electricity to convert carbon dioxide and water to multicarbon extracellular organic compounds. American Society for Microbiology. 2010;1:e00103-10.

142. Summers ZM, Gralnick JA, Bond DR. Cultivation of an Obligate Fe(II)Oxidizing Lithoautotrophic Bacterium Using Electrodes. American Society for Microbiology. 2013:4:e00420-12.

143. Xafenias N, Zhang Y, Banks CJ. Enhanced performance of hexavalent chromium reducing cathodes in the presence of Shewanella oneidensis MR-1 and lactate. Environ Sci Technol. 2013:47:4512-20.

144. Marshall CW, Ross DE, Fichot EB, Norman RS, May HD. Long-term operation of microbial electrosynthesis systems improves acetate production by autotrophic microbiomes. Environ Sci Technol. 2013;47:6023-9.

145. Bar-Even A, Noor E, Lewis NE, Milo R. Design and analysis of synthetic carbon fixation pathways. Proc Natl Acad Sci U S A. 2010;107:8889-94.

146. Dietz K-J, Heber U. Rate limiting factors in leaf photosynthesis. Biochimica et Biophysica Acta. 1984;767:432-43.

147. Herter S, Fuchs G, Bacher A, Eisenreich W. A Bicyclic Autotrophic CO2 Fixation Pathway in Chloroflexus aurantiacus. Journal of Biological Chemistry. 2002;277:20277-83.

148. Zarzycki J, Brecht V, Muller M, Fuchs G. Identifying the missing steps of the autotrophic 3-hydroxypropionate CO2 fixation cycle in Chloroflexus aurantiacus. Proc Natl Acad Sci U S A. 2009;106:21317-22.

149. Claassens NJ, Sousa DZ, Dos Santos VA, de Vos WM, van der Oost J. Harnessing the power of microbial autotrophy. Nat Rev Microbiol. 2016;14:692-706.

150. Berg IA, Kockelkorn D, Wolfgang Buckel FG. A 3-Hydroxypropionate/4 Hydroxybutyrate Autotrophic Carbon Dioxide Assimilation Pathway in Archaea. Science. 2007:318

151. Alissandratos A, Easton CJ. Biocatalysis for the application of CO2 as a chemical feedstock. Beilstein J Org Chem. 2015;11:2370-87.

152. Liao JC, Mi L, Pontrelli S, Luo S. Fuelling the future: microbial engineering for the production of sustainable biofuels. Nat Rev Microbiol. 2016;14:288-304.

153. Berg IA. Ecological aspects of the distribution of different autotrophic $\mathrm{CO} 2$ fixation pathways. Appl Environ Microbiol. 2011;77:1925-36.

154. Fast AG, Papoutsakis ET. Stoichiometric and energetic analyses of nonphotosynthetic CO2-fixation pathways to support synthetic biology 
strategies for production of fuels and chemicals. Current Opinion in Chemical Engineering. 2012;1:380-95.

155. Huber H, Gallenberger M, Jahn U, Eylert E, Berg IA, Kockelkorn D, Eisenreich W, Fuchs G. A dicarboxylate/4-hydroxybutyrate autotrophic carbon assimilation cycle in the hyperthermophilic Archaeum Ignicoccus hospitalis. Proc Natl Acad Sci U S A. 2008;105:7851-6.

156. Achim Mall JS, Huber C. Carolin Tschirner: Reversibility of citrate synthase allows autotrophic growth of a thermophilic bacterium. Science. 2018;359:363-7.

157. Nunoura T, Chikaraishi Y, Izaki R, Suwa T. A primordial and reversible TCA cycle in a facultatively chemolithoautotrophic thermophile. Science. 2018;359:559-63.

158. Kono T, Mehrotra S, Endo C, Kizu N, Matusda M, Kimura H, Mizohata E, Inoue T, Hasunuma T, Yokota A, et al. A RuBisCO-mediated carbon metabolic pathway in methanogenic archaea. Nat Commun. 2017;8:14007.

159. Schwander T, von Borzyskowski LS, Burgener S, Cortina NS, Erb TJ. A synthetic pathway for the fixation of carbon dioxide in vitro. Science. 2016:354.

160. Detweiler ZM, White JL, Bernasek SL, Bocarsly AB. Anodized indium metal electrodes for enhanced carbon dioxide reduction in aqueous electrolyte. Langmuir. 2014;30:7593-600.

161. Kortlever R, Peters I, Koper S, Koper MTM. Electrochemical CO2 Reduction to Formic Acid at Low Overpotential and with High Faradaic Efficiency on Carbon-Supported Bimetallic Pd-Pt Nanoparticles. ACS Catalysis. 2015;5: 3916-23.

162. Zhang S, Kang P, Meyer TJ. Nanostructured Tin Catalysts for Selective Electrochemical Reduction of Carbon Dioxide to Formate. Journal of the American Chemical Society. 2014;136:1734-7.

163. Nakata K, Ozaki T, Terashima C, Fujishima A, Einaga Y. High-yield electrochemical production of formaldehyde from $\mathrm{CO} 2$ and seawater. Angew Chem Int Ed Engl. 2014;53:871-4.

164. Kaneco S, Katsumata H, Suzuki T, Ohta K. Electrochemical Reduction of CO2 to Methane at the Cu Electrode in Methanol with Sodium Supporting Salts and Its Comparison with Other Alkaline Salts. Energy and Fuels. 2006;20: 409-14.

165. Shen J, Kortlever R, Kas R, Birdja YY, Diaz-Morales O, Kwon Y, LedezmaYanez I, Schouten K, Mul G, Koper MT. Electrocatalytic reduction of carbon dioxide to carbon monoxide and methane at an immobilized cobalt protoporphyrin. Nat Commun. 2015;6:8177.

166. Song Y, Peng R, Hensley DK, Bonnesen PV, Liang L, Wu Z, Meyer HM, Chi M, $\mathrm{Ma}$ C, Sumpter BG, Rondinone AJ. High-Selectivity Electrochemical Conversion of $\mathrm{CO} 2$ to Ethanol using a Copper Nanoparticle/N-Doped Graphene Electrode. ChemistrySelect. 2016;1:6055-61.

167. Zhang W, Qin Q, Dai L, Qin R, Zhao X, Chen X, Ou D, Chen J, Chuong T, Wu B, Zheng N. Electrochemical Reduction of Carbon Dioxide to Methanol on Hierarchical Pd/SnO2 Nanosheets with Abundant Pd-O-Sn Interfaces. Angew Chem Int Ed Engl. 2018;57:9475-9.

168. Qu J, Zhang X, Wang Y, Xie C. Electrochemical reduction of $\mathrm{CO} 2$ on RuO2/ $\mathrm{TiO} 2$ nanotubes composite modified Pt electrode. Electrochimica Acta. 2005;50:3576-80

169. Zhao K, Liu Y, Quan X, Chen S, Yu H. CO2 Electroreduction at Low Overpotential on Oxide-Derived Cu/Carbons Fabricated from Metal Organic Framework. ACS Appl Mater Interfaces. 2017:9:5302-11.

170. Yang H-P, Yue Y-N, Qin S, Wang H, Lu J-X. Selective electrochemical reduction of $\mathrm{CO} 2$ to different alcohol products by an organically doped alloy catalyst. Green Chemistry. 2016;18:3216-20.

171. Anthony C. How Half a Century of Research was Required to Understand Bacterial Growth on C1 and C2 Compounds; the Story of the Serine Cycle and the Ethylmalonyl-CoA Pathway. Science Progress. 2011;94:109-37.

172. Kalyuzhnaya MG, Yang S, Rozova ON, Smalley NE, Clubb J, Lamb A, Gowda GA, Raftery D, Fu Y, Bringel F, et al. Highly efficient methane biocatalysis revealed in a methanotrophic bacterium. Nature Communnications. 2013;4:2785.

173. Yishai O, Goldbach L, Tenenboim H, Lindner SN. Bar-Even A: Engineered Assimilation of Exogenous and Endogenous Formate in Escherichia coli. ACS Synth Biol. 2017;6:1722-31.

174. Bogorad IW, Chen CT, Theisen MK, WU TY, Schlenz AR, Lam AT, Liao JC. Building carbon-carbon bonds using a biocatalytic methanol condensation cycle. Proc Natl Acad Sci U S A. 2014;111:15928-33.

175. Siegel JB, Smith AL, Poust S, Wargacki AJ, Bar-Even A, Louw C, Shen BW, Eiben CB, Tran HM, Noor E, et al. Computational protein design enables a novel one-carbon assimilation pathway. Proc Natl Acad Sci U S A. 2015;112: 3704-9.

\section{Ready to submit your research? Choose BMC and benefit from:}

- fast, convenient online submission

- thorough peer review by experienced researchers in your field

- rapid publication on acceptance

- support for research data, including large and complex data types

- gold Open Access which fosters wider collaboration and increased citations

- maximum visibility for your research: over $100 \mathrm{M}$ website views per year

At BMC, research is always in progress.

Learn more biomedcentral.com/submissions 